\title{
Energy Retrofit Analysis Toolkits for Commercial Buildings: A Review
}

\author{
Sang Hoon Lee, Tianzhen Hong ${ }^{*}$, Mary Ann Piette, Sarah C. Taylor-Lange \\ Building Technology and Urban Systems Division \\ Lawrence Berkeley National Laboratory, \\ 1 Cyclotron Road, Berkeley, California, CA 94720, USA
}

*Corresponding Author.

Email: thong@lbl.gov,

Phone: (510) 486-7082,

Fax: (510) 486-4089 


\begin{abstract}
Retrofit analysis toolkits can be used to optimize energy or cost savings from retrofit strategies, accelerating the adoption of energy conservation measures (ECMs) in buildings. This paper provides an up-to-date review of the features and capabilities of 18 energy retrofit toolkits, including ECMs and the calculation engines. The fidelity of the calculation techniques, a driving component of retrofit toolkits, were evaluated. An evaluation of the issues that hinder effective retrofit analysis in terms of accessibility, usability, data requirement, and the application of efficiency measures, provides valuable insights into advancing the field forward. Following this review the general concepts were determined: (1) toolkits developed primarily in the private sector use empirically data-driven methods or benchmarking and provided ease of use, (2) almost all of the toolkits which used EnergyPlus or DOE-2 were freely accessible, but suffered from complexity, longer data input and simulation run time, (3) in general, there appeared to be a fine line between having too much detail resulting in a long analysis time or too little detail which sacrificed modeling fidelity. These insights provide an opportunity to enhance the design and development of existing and new retrofit toolkits in the future.
\end{abstract}

KEY WORDS: building energy retrofit, web-based applications, energy conservation measures, energy simulation, energy efficiency, retrofit analysis tools

\title{
1 Introduction
}

Currently, urban areas account for approximately two-thirds of the global energy demand [1, 2]. 
By 2050, urban areas are projected to produce roughly $80 \%$ of the global greenhouse gas emissions [1]. In response, many international agencies have increased their efforts to facilitate the adoption of building energy efficiency measures. The European Energy Performance in Building Directive (EPBD, 2002) requires all European Union member states to implement energy performance regulations, including minimum requirements for new buildings and energy performance certificates for existing buildings, during change of ownership [3]. In 2010, the California Green Building Standards Code (Calgreen) became the first statewide green building code to establish minimum green building standards for the majority of new residential and commercial construction projects [4]. Retrofitting existing buildings or adopting energy efficient technologies into new designs, offers considerable opportunities for reducing global energy consumption and greenhouse gas emissions [5]. However, methods to identify the most cost-effective energy savings for individual or combinations of retrofit measures, for a particular building, is a major technical challenge.

Web-based retrofit applications provide a service that can accelerate the adoption of energy efficiency measures by furnishing energy and cost savings estimates [6]. Common features of retrofit apps include energy conservation measures (ECMs) for electric lighting, building envelope, equipment (i.e. plug loads), heating, ventilation, and air conditioning (HVAC), service hot water and occupancy schedules. Examples of specific ECMs include installing daylighting sensors for interior lighting control, replacing wall and ceiling, or roof insulation, upgrading an HVAC rooftop unit with a high efficiency unit, adding an economizer, or upgrading to LED lights [7]. The building sector has a strong tradition of using simulation based tools for design optimization, to guide decision making, and perform energy diagnostics and evaluations. 
With increasing capabilities of web based service platforms, the reliability of web apps and online tools has become more important [8]. At a basic level, retrofit analysis toolkits can provide (i) an appealing interface for user input data and a graphical display of the outputs and, (ii) underlying engineering algorithms based on physical principles to calculate the thermal dynamics of components or at the whole building scale [6,9]. Building energy performance, influenced by physical building characteristics (structural design, climates, sub-component systems) and the stochastic interaction of occupants with sub-level components (i.e. lighting, HVAC systems etc.), is challenging to predict [9]. Building energy analysis tools, whether simplified energy calculations or complex dynamic simulations, combined with the input data, the scope, the cost, the user's skill and time, all influence the simulation speed, and the quality of the output $[8,10]$. In a recent scoping study, Wang [11] analyzed 14 existing commercial building tools, standards, and rating systems, reviling large gaps between calculated (modeled) and measured building energy use. As part of a larger effort to bridge this gap, published review papers have addressed a confluence of relevant building energy topics such as: (i) building environmental assessment tools [12-14], (ii) methodologies on the prediction of building energy consumption $[9,15,16]$, (iii) certification programs and performance assessment tools for residential buildings such as Home Energy Saver, CHREM [17-20], (iv) building energy efficient design [21] and, (v) whole building simulation programs [22]. This review employs a narrower focus, considering only energy retrofit toolkits, that provide technical requirements for ECMs, energy savings estimates, and investment cost analysis. Our review of building retrofit toolkits was conducted to better understand the status quo and different characteristics of existing tool, such as the target building type, target audiences, interface features, accessibility, calculation methods, scope and range of retrofit measures. Ultimately, 
this work will help to advance energy retrofit tools and accelerate their use in the building retrofit process.

\section{Methodology}

The recent attention on improving building energy efficiency has caused many toolkits to flourish and guide the assessment of building energy performance. Although there has been major efforts in the public and utility sectors to promote and accelerate retrofit activities, it is difficult to find information about tools, such as availability, applicability, and effectiveness. This review focuses on a twofold audience view, for the review of retrofit toolkits.

Firstly from the users' point of view, this review provides information about available tools to potentially use for a building retrofit project. These users could be (but are not limited to) building owners, engineers, facility managers, and energy service companies (ESCOs). Typically, building owners of larger commercial buildings have an ESCO conduct an energy audit for strategic energy management. However, retrofitting small and medium size commercial buildings (SMB) poses a huge challenge as SMB building owners usually lack the expertise and resources to conduct detailed audits to identify and evaluate cost-effective technologies for retrofitting buildings [23]. Small and medium commercial buildings less than $50,000 \mathrm{ft}^{2}\left(4,647 \mathrm{~m}^{2}\right)$ represent $95 \%$ of all commercial buildings, and consume $47 \%$ of the total energy of the commercial buildings [24]. It is crucial to provide free and publicly available retrofit tools that can be used for the SMB market. However, it is challenging for building owners and energy managers to obtain tangible information on the applicability of retrofit technologies, and to estimate energy or cost savings. Although a wide range of technologies are readily available, the main challenge still lies in how to identify the most effective retrofit measures to meet a 
building owner's investment criteria. This review highlights retrofit tool features and whether they are aligned for the SMB commercial sector [5].

Secondly, from the developers' point of view, the review discusses the trends in the development approaches and calculation methods. A variety of energy modeling methods have been developed and used to estimate energy performance of retrofit measures. Building energy performance and retrofit analysis incorporate predictions from models with different levels of fidelity. Models range from lowfidelity (i.e. statistical or black box models) to simplified reduced order models, to detailed physicsbased energy models [5]. Recently a rapid adoption of smart meters has filled the information gap in informing operational energy saving strategies that previously could not be realized with the calculationbased retrofit analysis [25]. Data-driven approaches, powered by smart meter data, measure the energy use data at short time intervals, enriching the analysis for energy profiling and diagnostics to provide operational improvements.

This review conducted a comprehensive search for the retrofit tools that are either publicly available, or privately offered by ESCOs. The retrofit tool review search covered tools developed by governments, research laboratories, universities, utilities, and private companies. It should be noted that there are many tools that can calculate estimated building energy usage with an aim to predict energy use, particularly for buildings in the design phase, and for energy audits in the operational phase. This review does not include native energy calculation engines such as EnergyPlus [26] and DOE 2.0 [27] which lack a graphical user interface for retrofit analysis. We have also omitted tools that do not provide a retrofit-oriented analysis such as Simergy [28] and OpenStudio [29], which are built upon EnergyPlus [26]. Although they are capable of estimating the energy savings for different measures, it is difficult for 
users to identify retrofit oriented technologies or obtain information for measure recommendations. Since this review is focused on retrofit tools applicable to commercial buildings, we do not include tools that target residential buildings such as the Home Energy Saver by Lawrence Berkeley National Laboratory (LBNL) [30], TREAT Energy Audit by Performance Systems Development [31], the National Energy Audit by Oak Ridge National Laboratory [32], or BEopt by National Renewable Energy Laboratory [33]. A total of 18 tools were identified and selected for this review based on their potential use for energy retrofit analysis for commercial buildings as shown in Table 1. This paper provides a review of the selected tools' main capabilities, energy calculation methods, energy conservation measures, and a general discussion on the limitations of modeling and applications.

Table 1: A list of the reviewed toolkits.

\section{Review of building energy calculation methods}

Retrofit tools generally rely on building energy calculation methods as the major portion of the computational process, driving the toolkit function, main features and output. The most common building energy modeling methods include (i) empirical data-driven methods, (ii) normative methods and (iii) physics-based energy modeling. A schematic comparing the interface, retrofit toolkit, the underlying building energy simulation engine, and the associated toolkits are presented in Figure 1.

Figure 1: A schematic detailing the general features of a retrofit toolkit and the toolkits reviewed separated by the type of the building energy simulation engine.

\subsection{Toolkits using empirical data-driven methods}

Data driven methods have been widely used to predict building energy usage, from simple 
benchmarking to more complex regression modeling, to relate building design and operational parameters with energy consumption. These methods rely on real measured data, smart meter data and pre-defined databases for benchmarking. Some of the challenges with empirically data-driven methods include: (1) the requirement of having training data to develop the model, (2) the model is limited to a specific building and may not be applicable to other buildings, and (3) there lacks a physic explanation of certain parameters of the building performance.

The regression model derived from statistical methods can be used to solve certain inverse problems. Different from the conventional energy modeling processes, the inverse statistical model derives inputs from known outputs [9], allowing a building design or operational parameter to be inferred when energy consumption data is available. Regression methods applied to existing data and inverse solving techniques can be used by engineers to quickly estimate the energy consumption of individual buildings with a few parameters or to be used by scholars to derive more information from city-wide energy consumption data. However, there is a major gap in this approach, in that the energy model does not capture the dynamics of the integrated effects of ECMs. An example of an integrated effect would occur during a lighting retrofit. Changing the lighting not only contributes to lighting energy savings, but also reduces the cooling load, thus reducing the space cooling energy consumption. For a quick summary, Table 2 and 3 describe the features of the empirically data-driven toolkits including input requirements, features, ECMs, and outputs. Specific details pertaining to each toolkit can be considered in the synopsis paragraphs in sections 3.1.1 to 3.1.7.

Table 2: A list of the toolkits using empirically data-driven statistical methods with the general input requirements. 
Table 3: A list of the toolkits using empirically data-driven statistical methods and highlighting primary features, gaps, general ECM categories and general outputs (updated from [6]).

\subsubsection{Buildings Performance Database (BPD)}

The Buildings Performance Database (BPD) is a web-based database that provides access to empirical building data on the actual whole building energy performance, physical and operational characteristics of commercial and residential buildings. This data can to be used for energy benchmarking and retrofit analysis (energy.gov/eere/buildings/building-performance-database). For database establishment, BPD aggregates data from several sources such as Energy Star Portfolio Manager, DOE's Commercial Energy Asset Score, the 2003 Commercial Building Energy Consumption Survey (CBECS) database, and the California Commercial End-Use Survey (CEUS) database. The database components include a building's energy usage, location, climate zone, building type, floor area, age, operational characteristics, and building systems. The outputs include a (i) Peer Group Tool, where users can compare the energy use of their own building to peer buildings, (ii) Performance Comparison Tool, allowing the comparison of two peer groups of buildings and, (iii) Application Programming Interface (API) which allows external software users to directly conduct analysis. Currently, the tool allows users to analyze the energy percent savings from a specific energy efficiency measure. Seventythree measures are available from six categories including air flow control, cooling, heating, lighting, window glazing layers and glazing type. The value of the BPD depends upon the amount and quality of data it contains. Particularly, the current development has limited energy data for buildings under 50,000 $\mathrm{ft}^{2}\left(4,645 \mathrm{~m}^{2}\right)$. In the future, when richer data sets are integrated, a larger variety of retrofit analyses will be possible. 


\subsubsection{C3 Commercial}

C3 Commercial, a web-based platform developed by C3 Energy, provides energy usage and retrofit recommendations to help utility companies engage small and medium-size building owners conduct building retrofits (3energy.com/product-commercial). The tool uses interval data from smart meters and the CEUS database to perform energy benchmarking. The energy consumption, broken into subcategories (annual, monthly and daily), is compared with average buildings as well as energy efficient buildings that are functionally equivalent (same type and floor area). Building profile information is collected from the input platform to identify a recommended list of energy saving ideas, tailored specifically to the user's building. The savings calculations are based on data driven inverse energy modeling, coupled with statistical analysis utilizing an existing ECM list from the Database for Energy Efficiency Resources (DEER). The output includes information on the recommended energy savings actions with cost and energy savings.

\subsubsection{Agilis Energy}

The web-based Agilis tool uses utility data to perform load shape analysis to evaluate building energy performance (agilisenergy.com). The tool identifies operational energy usage patterns and uses 3-D graphics to illustrate intraday temperatures, interval energy demand, occupancy, and energy system operations. Operational energy performance based on smart meter interval data and climate data is used to measure the energy performance across similar days and conditions to create a best-fit trend line to quantify energy and cost savings. The trend lines track energy consumption in real time, alerting the user 
of achieved savings. The tool conducts energy analysis using a statistical model dependent upon the smart meter data. Agilis Energy is not in the public domain, thus APIs are not open to allow further development by a third party.

\subsubsection{FirstFuel}

This web-based tool uses time series data analysis for building energy estimation and retrofit recommendations (firstfuel.com). The tool combines one year of hourly electricity consumption data from the utilities, hourly local weather data, and high level building data from geographic information systems to benchmark the building end-use energy performance, customize operational and retrofit recommendations, and verify energy savings from actions over time. The analysis is based on a smart meter, data-driven statistical model, and may support only limited detailed retrofit analysis. This effective energy performance and building operation tracking tool is best suited to customers whom may not have adequate technical knowledge (or the time) to collect or analyze large sets of building energy data. FirstFuel suggests that sixty-percent of the savings identified by their tool comes at a no or little cost.

\subsubsection{SIMIEN}

An online tool, developed by ProgramByggerne ANS, that performs energy simulations on the condition of buildings (residential and office buildings) to provide an operating range evaluation, energy calculation, energy labeling, comparison against building codes, cost savings, ventilation, space cooling and energy measurement (programbyggerne.no). This is a Scandinavian based tool, requiring extensive 
inputs and the modification of baseline parameters. The benchmarking is compared with TEK07 and TEK10 current Norwegian energy consumption patterns [34, 35]. With the energy delivered information, the building is given a grade, based on the evaluation and compared against low energy, passive building criteria [36]. Assumptions include fixed values for power and heat gains from lighting, equipment, people, domestic heating, and set-point temperature. Energy measures focus on glass area, U-values, thermal bridges, leakage, fan power and the efficiency of the heat recovery system, heat dissipation and energy frame, using the Oslo, Norway climate. A separate tool, Air Quality in Buildings (SCIAQ) performs dynamic simulations on zones/rooms to assess adequate indoor air quality, net energy and dimensioning of heating systems, ventilation and space cooling. Challenges with using this tool occur as most of the documentation is in Norwegian.

\subsection{Toolkits using normative calculations}

A reduced-order model uses simple input and output data providing a quick evaluation of the energy performance, requiring an appropriate model structure and normative values of the model parameters. There are a variety of forms of reduced order models with the resistor-capacitance (RC) model being one of the most common ways. An RC model treats the building as an electric circuit with thermal resistances and capacitances [37]. Another well-known reduced-order model, the normative method, is a first order energy model based on quasi-steady-state heat balance equations. The normative method follows the calculation standards developed by the European Committee for Standardization (CEN) and the International Organization for Standardization (ISO) [37] which defines the calculation method as using a set of normative statements containing the physical building parameters and building systems for 
different building types. The method calculates the energy use at different levels of the thermal energy demand, delivered energy per carrier, primary energy and emissions. Through simplicity and unified modeling assumptions, the method forms the basis for assessing building energy performance in a standardized and transparent way. Traditionally used for energy performance rating [38, 39], now normative calculations include retrofit analysis for large scale energy assessment [37, 40]. The reducedorder models may not be as accurate as detailed physics-based models, yet there are many use cases with advantages such as computational efficiency and fewer inputs required. Three toolkits are featured using the normative calculation, the Chicago Loop Energy Retrofit Tool, HELiOS Building Efficiency, and Retroficiency, with Retroficiency using a combination of normative and statistical calculation engine (Table 4 and Table 5).

Table 4: A list of the toolkits using normative calculation methods with the general input requirements.

Table 5: A list of the toolkits using normative calculation methods and highlighting the primary features, gaps, general ECM categories and general outputs (updated from [6]).

\subsubsection{Chicago Loop Energy Retrofit Tool}

The Chicago Loop Energy Retrofit Tool by Argonne National Laboratory is intended for the retrofits of buildings within the Chicago Loop (the central business district of Chicago) and enables retrofit analysis at the aggregate level and at the individual building level [41]. The aggregate analysis level inspects energy improvement scenarios for any collection of buildings within the Chicago Loop area, utilizing Chicago weather files. The tool helps determine a level of intervention in the energy performance of certain buildings in order to reach an energy improvement target. At the individual level, the tool enables a selection of ECM options for optimal energy improvement of the selected building 
[42]. The goal is to allow users to evaluate retrofits of large portfolios of buildings, while alleviating burdens associated with data collection, model construction, and computation [41]. The tool uses the normative calculation method, based on the monthly balance of heat gains and heat losses determined in quasi-steady-state conditions. The tool calculates the energy performance at different levels of thermal energy demand, delivered energy per carrier, primary energy and emissions. A large variety of ECMs, including heating, cooling, ventilation, lighting, plug loads, pumps, and domestic hot water systems can be applied for energy retrofit of existing commercial buildings. The tool enables the creation of different ECM pallets that test ECMs and group them into retrofit scenario pallets. When a retrofit ECM pallet is chosen for retrofit analysis, affected input parameters feed into the energy model, and the energy performance is updated. The current method only allows single zone modeling, which does not consider dynamic conditions between internal zones and thus cannot capture dynamic behaviors and controls of HVAC systems.

\subsubsection{HELiOS Building Efficiency}

HELiOS, a private company, provides an integrated web-based platform allowing non-experts such as building owners and facility managers to rapidly analyze their retrofit opportunities (heliosbe.com). Among the suite of tools, the Energy Modeling Tools for Retrofit Analysis uses reduced order models (normative energy model) that are based on the CEN / ISO standards [37]. The toolkit uses Bayesian algorithms to calibrate the energy model to actual building energy use. The platform can reduce the modeling time that is viable for a retrofit project from one to two weeks of building energy expert time to less than one hour. The energy model, in combination with Bayesian calibration, has been validated 
with EnergyPlus [26] and DOE 2.0 [27, 43]. The HELiOS's hourly model allows more accurate analysis under dynamic building operating conditions and climate conditions for retrofit analysis. HELiOS Retrofit Explorer allows for rapidly recommending retrofit measures out of a large library of parameterized 100 ECMs and is capable of analyzing advanced building technologies for their retrofit analysis. HELiOS also provides a unique toolset of performance risk and financial analytics, EE-RISK designed to provide confidence in the value of building energy retrofits and thus facilitate project financing. The suite of energy retrofit analytics is integrated with baseline regression analysis and Measurement and Verification capability based on the International Performance Measurement and Verification Protocol.

\subsubsection{Retroficiency}

Retroficiency, a private company, will evaluate building energy performance and provide an energy retrofit analysis report for commercial building owners and energy portfolio managers (retroficiency.com). The Virtual Energy Assessment (VEA) analyzes interval energy data from smart meters to understand how a building responds to weather, occupant behavior, and systems operation, and provides retrofit recommendations. The Automated Energy Audit (AEA) evaluates energy performance using a simplified normative calculation method, and generates life cycle cost analysis and payback period, for select ECMs. The underlying calculation engine performs pattern recognition, developing a statistical model for VEA and a simplified physics-based calculation for AEA. The tool is dependent on a reduced-order energy model, which limits detailed analysis when considering dynamic conditions of HVAC system operations and controls. The tool is not in the public domain, thus APIs are 
not open to the public for further development by a third party.

\subsection{Toolkits using physics-based energy modeling}

Physics-based advanced energy modeling, the highest fidelity and the most complex option, can provide accurate energy use results of real buildings. Most of the retrofit toolkits based on physics-based energy modeling utilize publicly available open source simulation engines, such as DOE 2.2 (eQuest) and EnergyPlus [26]. EnergyPlus has the capability to provide in-depth analysis of complex mechanical systems, often exceeding the capabilities of other simulation tools (e.g. variable refrigerant system, radiant cooling and heating system, and natural ventilation). Although EnergyPlus helps energy modeling professionals assess building energy performance, the simulation engine is without a graphical user interface, proving to be challenging to use without having substantial knowledge of energy modeling and building systems. Table $6(a, b)$ and 7 describe the features of the toolkits which use either eQuest or EnergyPlus as the main calculation engine. Physics-based modeling methods are configured in two different ways. One utilizes energy simulation engines by APIs under their toolkit to conduct a real time energy simulation. For example, OpenStudio, built atop of the EnergyPlus simulation engine, allows external software retrofit applications to directly conduct energy analysis. The other uses a presimulation database, which provides a direct resource to conduct quick retrofit analysis. The presimulation utilizes prototype building models representing retrofit target buildings in various climate locations and vintages. It is found that EnergyPlus is mostly used for large-scale pre-simulation due to its flexible software environment for parametric simulations in high performance computing clusters. Table 6(a,b): A list of the toolkits using energy simulation engines with the general input requirements. 
Table 7: A list of the toolkits using energy simulation engines and highlighting primary features, gaps, general ECM categories and general outputs (updated from [6]).

\subsubsection{Commercial Building Energy Asset Score Tool}

The Commercial Building Energy Asset Score is web-based tool which provides a voluntary energy performance rating, to evaluate the physical characteristics of existing buildings (buildingenergyscore.energy.gov). The building physical characteristics include the building envelope (location, type, footprint), construction properties (roof, floor, wall, window type and glass type) HVAC systems, lighting systems, domestic hot water systems, and heating fuel. The potential energy score is based on the ECM recommendations provided by the (i) Facility Energy Decision System (FEDS), a pre-calculated and compiled performance database of retrofit measure packages (not publicly available for review) and (ii) an energy model using OpenStudio, built atop of the EnergyPlus simulation engine [26]. For operational parameters, the tool uses predetermined assumptions based on ASHRAE Standard 90.1 [44]. Plug loads, operation schedules, and occupant behaviors are not a part of the retrofit recommendations. The tool generates a score for the building and also scores recommended retrofits. The scoring evaluation provides full building energy performance, the overall energy efficiency at standard operating conditions per building type, the payback information and insights into the building's energy efficiency potential.

\subsubsection{Simuwatt Energy Auditor}

Simuwatt Energy Auditor is a cloud-based software solution which provides commercial building energy audits, while preserving the data to facilitate reporting and portfolio-wide tracking 
(simuwatt.com). Energy auditors have access to an extensible library of building components [45] which links with the OpenStudio platform [29], and geometry capturing technology provided by concept3D. The tool, intended for full energy audits of large federal office buildings, combines a virtual audit with a quick onsite assessment for rapid energy modeling. The tool can improve energy audit effectiveness, but requires auditors to have knowledge of building systems and operations to create a valid and detailed building energy model.

\subsubsection{Consortium for Building Energy Innovation (CBEI) Tools}

Consortium for Building Energy Innovation tools are a suite of web simulation tools organized around four different interfaces, namely (i) lite, (ii) partial, (iii) substantial, and (iv) comprehensive (research.cbei.psu.edu), listed in order of model complexity. The lite simulation allows building owners to input utility data, building location and type and generate regression models which estimate the energy use based on the ASHRAE inverse modeling method [46]. The partial simulation allows for estimating the building energy performance, using the Design Advisor Tool (DAT), a simulation engine developed by MIT [47, 48]. An uncertainty quantification feature is added to inform risk when energy performance does not meet the as-designed performance. The substantial simulation, intended for building auditors, uses energy models calibrated from climate and measured data, to conduct energy audit and retrofit recommendations. The comprehensive tool option interfaces with the Retrofit Manager Tool (RMT) with nineteen ECMs, in the general categories of HVAC, enclosure, lighting, plug loads and occupancy schedule. The comprehensive simulation, intended for experienced energy managers and consultants, is based on EnergyPlus simulations through the OpenStudio platform from web-interface 
inputs.

\subsubsection{California Building Energy Code Compliance for Commercial (CBECC-Com)}

The California Building Energy Code Compliance (CBECC-Com) is an open-source, nonresidential compliance software tool developed by the California Energy Commission, for code and rating authorities to demonstrate energy code compliance (bees.archenergy.com) [49]. The tool, designed for 16 California climate zones, shows compliance with 2013 Title-24 Building Energy Efficiency Standards [50] for newly constructed buildings, buildings undergoing additions or alterations, or buildings with partial compliance. The core simulation engine is EnergyPlus, with OpenStudio, and Trimble SketchUp for capturing the building geometry. The inputs, aside from the geometry, are obtained from the CBECC-Com user interface. Each model is translated into an EnergyPlus input data file (IDF) and then simulated using the EnergyPlus engine. CBECC-Com performs three automated simulations, namely, (1) the proposed design annual simulation, (2) the standard design sizing simulation to determine HVAC system sizes, and (3) the standard design (baseline) meeting the prescriptive requirements of Title 24-2013 [50]. The outputs include the generation of a compliance report, summarizing the building's compliance related characteristics, and forms for building permit submission. The tool provides an open Application Programming Interface (API) to allow third party software developers to utilize the functionality of the CBECC-Com compliance checking module. This tool focuses more on demonstrating compliance with Title 24 energy codes for newly constructed nonresidential buildings, rather than being specifically retrofit oriented. 


\subsubsection{EnCompass}

EnCompass, uses benchmarking techniques to evaluate the building energy performance and potential energy savings for the retrofit of large office buildings located in the Chicago area (encompass.energyimpactillinois.org). EnCompass relies on a pre-simulated (use of EnergyPlus) database which stores more than 275,000 energy models and based on the DOE commercial reference buildings (modified from medium and large offices) for building characteristics, with other parameters defined from multiple resources, including the 2003 CBECS, ASHRAE Standard 90.1, and the Building Owners and Managers Association (BOMA) Experience Exchange Report. With the user's building input information, the tool selects a best-fit baseline energy model from the database and presents the pre-simulated results. The selected best-fit model, representing the candidate building, is compared against the industry average energy use intensities (for the Midwest region) defined in the 2003 CBECS, using the ENERGY STAR Target Finder. Users receive their benchmarking results and a set of recommended ECMs with associated energy and cost savings. Also, the tool provides information on local and federal incentives, utility programs, and service providers who can fund or implement the selected ECMs [51]. Although the tool streamlines an energy efficiency evaluation by providing benchmarking, it is designed only for large commercial buildings in the Chicago area, limited to buildings greater than $800,000 \mathrm{ft}^{2}$ in the downtown area and $165,000 \mathrm{ft}^{2}$ for suburban area.

\subsubsection{The Energy Savings Benefits Evaluator for Enterprise Customers (Evaluator)}

The Evaluator, developed by Energy \& Environmental Modeling and Solutions LLC, provides a quick analysis and screening of the potential energy savings of commercial buildings for the New York 
State Energy Research \& Development Authority (www.energyenviromodeling.com/models.html) [52]. The Evaluator considers the technical, financial, and environmental operational aspects of the existing building equipment and suggests schedule changes and equipment replacement for efficient energy use and to reduce greenhouse gas emissions. The Evaluator also benchmarks the energy performance, via the ENERGY STAR Building Program, enabling peak demand analysis and allowing for peak load reduction strategies for the State of New York [53]. Inputs include basic building profile information through a simplified web input interface for EnergyPlus model creation. The Evaluator creates an EnergyPlus model to calculate the building thermal load profile, then the tool uses separate algorithms provided in the ASHRAE Handbook [54] to conduct HVAC equipment simulations. This split simulation methodology approach may reduce simulation time, but the real benefit of EnergyPlus, capturing the dynamics of HVAC systems under different operational conditions, is not realized. The tool contains several modules for evaluation of separate or combined efficiency measures in lighting, HVAC schedules and temperature set points, HVAC cooling equipment optimization and motor upgrade. The results include hourly, daily, monthly and annual amounts of used energy and fuel, generated green-house gas (GHG) emissions, and energy and fuel costs for different scenarios of equipment and operation improvements.

\subsubsection{Commercial Building Energy Saver (CBES)}

The Commercial Building Energy Saver (CBES), focusing on small and medium size commercial buildings, uses web service application programming interfaces (APIs) based on the identified functional requirements (cbes.lbl.gov). The CBES retrofit software, in conjunction with the user input 
data, analyzes the energy performance pre- and post-retrofit and provides energy savings estimates and economic analysis for select and packaged measures. The software provides energy benchmarking, using external energy benchmarking software APIs including EnergyIQ and ENERGY STAR Portfolio Manager. Additionally, three levels of retrofit analysis, depending upon the degree of the input data, are provided as follows (i) Level 1: No- or low-cost improvement analysis uses load shape analysis based on the statistical models, (ii) Level 2: Preliminary retrofit analysis uses a database that compiles the presimulated energy performance using prototype buildings with retrofit measures, and associated cost data for measures [55], and (iii) Level 3: Detailed retrofit analysis using real time simulation that calculates the energy performance of the building with user configurable retrofit measure(s). Over 70 detailed retrofit measures are included, with a calibration feature and servicing California and select cities around the United States. The CBES toolkit allows for the input of weather data for different cities. The output includes indoor environmental quality information, annual site energy, carbon dioxide emissions, energy cost savings and energy savings. CBES is one of the most comprehensive tools to date.

\subsubsection{Customized Calculation Tool (CCT)}

The Customized Calculation Tool provides an estimate of the energy savings for ECMs specific to the Pacific Gas and Electricity (PG\&E), San Diego Gas \& Electricity (SDG\&E), and Southern California Edison (SCE) policies. CCT is available as a stand-alone program for PG\&E and SDG\&E and web-based for SCE. CCT specializes in preparing application packages designed to simplify and facilitate the completion of the required forms, energy savings estimate, incentives, and retrofit project application form for statewide utility customers in California. The energy savings calculations use 
prototype buildings that reference the 2004/2005 Database for Energy Efficiency Resources (DEER) [7]. Upon choosing the selected building type, the tool asks for detailed input of the building to estimate the energy savings and peak demand reduction. There are 40 ECM categories in air conditioning, refrigeration, gas, and lighting systems. To fully understand available ECMs, more references are needed and explanation on how the technology can be applicable to a particular building type. The energy savings are calculated using Engage, a modified version of eQuest using DOE 2.2 as the simulation engine for California climates. CCT provides outputs including peak demand and estimated energy savings for the baseline and the proposed building as well as total incentives. Engage (version v1-20 prepared in 2007), is incapable of supporting a retrofit analysis of an emerging technology that is market ready, for example the variable refrigerant systems (VRF) and natural ventilation.

\subsubsection{Commercial Building Analysis Tool (COMBAT)}

Commercial Building Analysis Tool, a stand-alone retrofit tool, is designed to identify costeffective ECMs, for commercial buildings (only retail and hotel) in China (china.lbl.gov/tools/combat) [56]. COMBAT was designed for easy use and quick retrofit analysis to facilitate policy makers, facility managers, and building retrofit practitioners in estimating energy and cost savings and the payback period for a retrofit investment [57]. The tool uses prototype buildings, represented as EnergyPlus models, to create a database of pre-simulation energy models with a large number of ECMs. The tool allows users to add measured energy usage data for calibration. For retrofit analysis, the tool provides pre-determined ECMs including envelope, lighting, appliances, simplified HVAC systems, and combinations of interacting measures. The use of the pre-simulated database allows (i) users to avoid 
time consuming simulations, (ii) select default retrofit measures, (iii) customize input cost, (iv) compare before and after retrofit conditions, (v) calculate building energy saving, retrofit cost and investment payback period and, (vi) calculate a single measure's energy saving and cost-effective performance.

\subsubsection{EnergyIQ}

EnergyIQ provides action-oriented benchmarking assessment of non-residential buildings compared against peer group buildings (energyiq.lbl.gov). Action-oriented benchmarking extends whole-building energy benchmarking to include component energy use metrics and system analysis [58, 59]. EnergyIQ provides a standardized opportunity for assessment, based on benchmarking results and coupled with decision support information for action planning. EnergyIQ benchmarks energy use, costs, and features for 62 California building types (2800 buildings from the CEUS database) and at the national level, using the 2003 CBECS database. The tool compares whole building performance against filtered peer building groups, allowing users to specify energy related targets depending on selected groups. Based on the user's input (including meter data) the output includes metrics such as energy per carrier, system specific end use, peak demand as well as benchmarking of various building system features. The

analysis is based on over 65,000 eQuest pre-simulated data representing retrofit measure-building combinations, integrating 50 energy conservation measures (ECMs) in the subset of CEUS buildings. Additionally, EnergyIQ is one of the few building energy retrofit tools which provide a carbonemissions calculation for the energy consumed in the building.

\section{Discussion}


The synopsis of the toolkit review, provides a better understanding of the limitations and gaps. These insights may help stakeholders address shortcomings or lead to improvements. In particular the following issues were identified:

(1) Emerging technologies for building retrofits that are market ready are not included or cannot be accurately evaluated using existing tools:

To name a few, toolkits BPD, EnergyIQ, Chicago Loop Energy Retrofit Tool, C3 Commercial, Retroficiency, Agilis Energy, EnCompass, and First Fuel provide a limited amount of ECMs. Expansion ability of ECMs would require further implementation by each program. Simuwatt Audit is currently developing more ECMs and the DOE Commercial Building Energy Asset Score Tool and CCT are supported or limited by their databases. This issue of expansion and technology change is one limitation which needs to be overcome by most of the web-based toolkits.

(2) Tools with limited geography, therefore limiting scope.

Some toolkits are specifically designed for certain building types or geographic regions, automatically eliminating their applicability to specific users. For example, COMBAT applies primarily to Chinese hotels and shopping malls in Shanghai, China and SIMIEN applies mostly to Nordic regions. CBES and CCT target California based customers, whereas the Chicago Loop Energy Retrofit Tool and EnCompass targets building in the greater Chicago area and Evaluator for New York State. However, these tools are developed for specific scope of their project, they potentially be adopted for other geographic locations.

(3) Tools that consider integrated effects when adopting multiple retrofit measures. 
Most toolkits conduct single major analysis and to not account for integrated effects. The toolkits with the most complexity provide results from ECM packages, taking into account integrated effects, more indicative of what actually happens during operation. Some tools with this capability include the CBES toolkit, EnCompass, Evaluator, Chicago Loop Energy Retrofit Tool, and Retroficiency. BPD provides retrofit strategies based on real projects and thus provides ECM specific information.

\section{(4) The challenge of identifying calibrated models}

Many of the toolkits failed to acknowledge or use model calibration, although calibration can be critical to achieving predictive success. Calibration is a manual or automatic procedure that aligns the model with the user input data and enables an improved representation of the actual building [60]. Although retrofit tools use calibrated energy models for their retrofit analysis, their underlying calibration techniques are unclear. In common practice, when energy service companies do a retrofit project often the calibration parameters relate directly to the ECM. In addition, calibration is limited in many cases due to the fact that measurement data is limited and has certain accuracy. Often, calibration techniques are treated as an extension of energy modeling and retrofit analysis. Major challenges in calibration techniques include (1) the identification of parameters that dominate a sensitivity of the energy performance and, (2) the propagation of the uncertainty of those parameters. Common calibration techniques include Bayesian calibration, referring to the generally fitting of a statistical model. Toolkits that use calibration include COMBAT, SIMIEN and CBES. The CBES Detailed Retrofit Analysis employs advanced automated calibration algorithms to attune inputs prior to simulating the energy savings of ECMs. For this calibration technique a model is considered calibrated if the differences between the simulated and measured monthly electricity and natural gas data are small enough to meet 
the ASHRAE Guideline 14 [61] criteria (i.e. the Normalized Mean Bias Error (NMBE) is less than 5\%, and the Coefficient of Variation of the Root Mean Square Error (CVRMSE) is less than 15\%). For a pattern-based calibration approach, 16 model parameters are tweaked one parameter at a time and run in EnergyPlus.

In agreement with Crawley et al. [22], the retrofit tool community lacks a clear language to describe the scope and capabilities offered by building energy analysis tools. Of the toolkits reviewed, each boasts different features, from auditing, to compliance rating to economic analysis or $\mathrm{CO}_{2}$ savings. All toolkits provided ECMs in the general categories of electric lighting, building envelope, equipment plug loads and HVAC systems. Only $90 \%$ of the tools provided retrofit measures for service hot water, whereas $80 \%$ of the tools provided some mention of occupant density or occupancy schedules. All of the tools included some metric of energy and cost savings. The metrics less often considered included GHG emissions (15\% of the tools), IAQ (25\% of the tools) and water savings (15\% of the tools), suggesting ample opportunity to expand existing toolkits to evaluate a wider range of environmental parameters.

Understanding the need for new features and capabilities of energy analysis tools is extremely important to identify robust and low cost techniques to reduce energy use in buildings. From this review, some of the most common challenges with toolkit design include: (i) tool limitations in not allowing users to define specific energy conservation measures (ECMs) to evaluate their individual energy savings and cost effectiveness, (ii) the lack of accurate model calibration methods, (iii) difficulty in analyzing new buildings due to new codes and standards, (iv) difficulty incorporating new efficiency measures, (v) using predefined operating assumptions which may result in differences between actual and simulated results, (vi) focusing only on technological upgrades, leaving out potential savings 
opportunities associated with occupant behavior, (vii) limitations associated with tool specific selection criteria or weighting factor for ECM assignments. Action-oriented or generalized benchmarking tools proved to be limited to the databases that they query, in turn limiting the scope of the tool. Additionally, pre-simulated data has to be periodically updated to capture new retrofit measures. The feasibility for users to establish good information and quality output often hinged on input data with inherent user error. Semantic technological advancement of web technology can offer a promising opportunity to improve the clarity (in turn the quality) of the required input data and expedite the process of information acquisition and collection [62]. The transition from toolkit to actual retrofit implementation, introduces a new set of challenges including modeling mismatch errors due to building specific features [5] and the fact that different measures have a different impact on associated building unique subsystems. Retrofit analysis relies on the prediction of the building energy performance improvement. Different tools offer different prediction reliabilities with different uncertainties. In general, high fidelity physics-based modeling methods lead to more accurate results as they represent the dynamics of physical systems in the energy models. The empirical data-driven methods typically provide black box results as they are based on the statistical regression techniques. Although more detailed energy modeling brings results closer to actual building performance, it should be noted that the level of the input data requirement is higher than those toolkits that perform less detailed modeling. This potentially causes a high level of uncertainty, unless inputs are carefully collected and used in the energy models. It is important for users to recognize that the use of tools helps retrofit decision making under uncertainties. A risk assessment on retrofit decisions under uncertainties is a new emerging area in retrofit projects [63]. The many other uncertainties such as service change, human behavior change, 
government policy change, all of which shift the direction of efficiency measures, also impact toolkit performance.

Lastly, one issue that plagues the web-based retrofit applications is longevity and upkeep. RESEM-CA (2004), an updated version of the 1991 RESEM tool [64], performed an economic analysis of building retrofits, calculated life-cycle cost and payback based on energy savings for pre- and postretrofit, and provided decision support [65]. Today the energy calculation method is no longer used in current energy simulation tools and the tool is no longer publically available nor supported.

The research areas to improve retrofit analysis leveraging building energy modeling include (i) risk assessment, mitigating the high degree of uncertainty associated with the tools to improve actual building energy efficiency, (ii) interoperability, the linking of tools with other tools, (iii) incorporating human factors that directly affect building energy use, and (iv) expanding output parameters to include more environmental indicators.

Despite these challenges, retrofit toolkits are a critical element to provide information to achieve a sustainable built environment. Alajmi et al. [66] demonstrated that ECMs implemented with no or low cost investment saved $6.5 \%$ of building annual energy consumption, while ECMs with considerable capital investment can save up to $49 \%$ of the annual energy consumption. The cumulative effect can have a significant impact with, FirstFuel suggesting their tool found enough savings to remove two coalfired power plants from use. ECM recommendations and economic analysis proves to be an effective approach to identify the best retrofit solution per building [5].

\section{Conclusions}


The objective of model-based building retrofit optimization is to determine the most cost effective retrofit technologies to achieve enhanced energy performance while maintaining satisfactory indoor comfort. Presented was a review of 18 building energy retrofit analysis toolkits that provide energy and cost savings solutions for commercial buildings. Arranged by the underlying building energy modeling engine (empirical data-driven methods, normative calculation or physics-based advanced building energy modeling), each selected tools' uniqueness and main capabilities were highlighted. The general concepts identified are as follows:

(1) In general, toolkits developed primarily in the private sector, with no public accessibility, use empirical data-driven methods or benchmarking providing easy use.

(2) Almost all of the toolkits which used EnergyPlus or DOE 2 are freely accessible, but suffer from, complexity, longer data input and simulation run time.

(3) In general, there appeared to be a fine line between having too much detail resulting in a long analysis time or too little detail which sacrificed modeling veracity.

(4) This issue of expansion and technology change is one limitation which needs to be overcome by most web-based toolkits.

(5) Metrics less often considered included GHG emissions, IAQ and water savings, suggesting ample opportunities to expand existing toolkits to evaluate a wider range of environmental parameters.

The findings from this review, in general, identified toolkit shortcomings and pinpointed different trends in usability, fidelity and analysis type. All of these insights provide an opportunity to enhance the design and development of existing and new retrofit toolkits in the future. 


\section{Acknowledgements}

This review is part of a project, funded by the California Energy Commission, under the Public Interest Energy Research Program Award No. PIR-12-031. This work was also supported by the Assistant Secretary for Energy Efficiency and Renewable Energy, the U.S. Department of Energy under Contract No. DE-AC02-05CH11231. The tools reviewed were recommended by the stakeholders as part of this project and the intent is not to advertise or criticize the toolkits, rather to provide information. The toolkits may have been altered or updated following the date of the manuscript submission. The authors would like to thank Vojislav Novakovic and Jens Toennesen for their input.

\section{References}

[1] Bose RK. Energy efficient cities: assessment tools and benchmarking practices. World Bank Publications; 2010.

[2] Grubler A and Fisk D. Energizing sustainable cities: assessing urban Energy. Routledge; 2012.

[3] Van Dijk H, Spiekman M, de Wilde P. A monthly method for calculating energy performance in the context of European Building Regulations, Ninth International IBPSA Conference, Montreal Canada, 2005.

[4] California Building Standards Commissions and the International Code Council, Guide to the 2013 California Green Building Standards Code (Nonresidential). Arvia P. Ed., California Building Standards Commission The European Parliament and the Council of the European Union, 2002. Directive 2002/91/EC. Of the European Parliament and of the Council of 16 December 2002 on the energy 
performance of buildings, Official Journal of the European Communities, 4.1.2003, pp. L 1/65.

[5] Ma Z, Cooper P, Daly D, Ledo L. Existing building retrofits: Methodology and state-of-the-art, Energy and Buildings, 2012; 55:889-902.

[6] Lee SH, Hong T, Piette MA. Review of Existing Energy Retrofit Tools, Ernest Orlando Lawrence Berkeley National Laboratory, LBNL-6774E, 2014.

[7] Itron Inc. and JJ Hirsh \& Associates Synergy Consulting Quantum Inc., Database for Energy Efficiency Resources (DEER) Updated Study, Final Report, 2005

[8] Perez-Lombard L, Ortiz J, Gonzalez R, Maestre IR. A review of benchmarking, rating and labelling concepts within the framework of building energy certification schemes. Energy and Buildings 2009; 41: $272-278$.

[9] Zhao H-X, and Magoules F. A review on the prediction of building energy consumption, Renewable and Sustainable Energy Reviews 2012; 16: 3586-3592.

[10] Al-Homoud MS. Computer-aided building energy analysis techniques. Building and Environment 2001; 36(4):421-33.

[11] Wang N. Development of an Online Toolkit for Measuring Commercial Building Energy Efficiency Performance, Scoping Study, Final Report PNNL-21563, Pacific Northwest National Laboratory, Richland, Washington, 2013.

[12] Happio A and Viitaniemi P. A critical review of building environmental assessment tools. Environmental Impact Assessment Review 2008; 28: 469-482.

[13] Ding G.K.C. Sustainable construction- The role of environmental assessment tools. Journal of Environmental Management, 2008; 86:451-464. 
[14] Burnett, J., City buildings-Eco-labels and shades of green! Landscape and urban planning, 2007, $83,29-38$.

[15] Neto AH and Fiorelli FAS. Comparison between detailed model simulation and artificial neural network for forecasting building energy consumption. Energy and Buildings 2008; 40: 2169-2176.

[16] Yang J, Rivard H, Zmeureanu R. On-line building energy prediction using adaptive artificial neural networks. Energy and Buildings 2005; 37: 1250-1259.

[17] Mills E. The Home Energy Saver Documentation of Calculation Methodology, Input Data, and Infrastructure. Lawrence Berkeley National Laboratory, LBNL-51938, 2005; 1-95.

[18] Horvat M. and Fazio P. Comparative Review of Existing Certification Program and Performance Assessment tools for residential buildings. Architectural Science Review 2005; (48:1): 69-80.

[19] Bourassa NJ, Rainer L, Mills E, Glickman J, The home energy scoring tool: A simplified asset rating for single family homes. Ernest Orlando Lawrence Berkeley National Laboratory, LBNL-5714E, 2012.

[20] Kavgic M, Mavrogianni A, Mumovic D, Summerfield A, Stevanovic Z, Djurovic-Petrovic M. A review of bottom-up building stock models for energy consumption in the residential sector. Building and Environment 2010; 45: 1683-1697.

[21] Pacheco R, Ordonez J, Martinez G, Energy efficient design of building: A review. Renewable and Sustainable Energy Reviews 2012; 16: 3559-3573.

[22] Crawley DB, Hand JW, Kummert M, Griffith BT. Contrasting the capabilities of building energy performance simulation programs. Building and Environment 2008; 43: 661-673.

[23] Preservation Green Lab. Realizing the Energy Efficiency Potential of Small Buildings 2013. 
[24] Janda KB, and Parag Y. A Middle-out Approach for Improving Energy Performance in Buildings. Building Research \& Information 2013; 41: 39-50.

[25] Hong T, Yang L, Hill D, and Feng W. Data and Analytics to Inform Energy Retrofit of High Performance Buildings. Applied Energy 2014; 126: 90-106.

[26] U.S. Department of Energy (DOE). Getting Started with EnergyPlus, Basic Concepts ManualEssential Information You Need about Running EnergyPlus, The Board of Trustees of the University of Illinois and the Regents of the University of California through the Ernest Orlando Lawrence Berkeley National Laboratory 2013; 1-68.

[27] Hirsch JJ. Welcome to DOE2.com, the Home of DOE 2 based Building Energy Use and Cost Analysis Software. Available at: http://www.doe2.com/ [Accessed at April 15, 2015].

[28] O’Donnell J, Maile T, Settlemyre K, and Haves P. A Visualization Environment for Analysis of Measured and Simulated Building Performance Data. 13th Conference of International Building Performance Simulation Association, Chambéry, France, August 26-28, 2013.

[29] Guglielmetti R, Macumber D, Long N. OpenStudio: An Open Source Integrated Analysis Platform, National Renewable Energy Laboratory, Conference Paper (NREL/CP-5500-51836) 2011; 1-9.

[30] LBNL. Home Energy Saver. Available at: http://homeenergysaver.lbl.gov/consumer/ [Accessed at April 15, 2015].

[31] Performance Systems Development. TREAT Energy Audit Software Available at: http://psdconsulting.com/software/treat/ [Accessed at April 15, 2015].

[32] U.S. DOE. National Energy Audit (NEAT). Available at http://apps1.eere.energy.gov/buildings/tools_directory/software.cfm/ID=304/pagename=alpha_list 
[Accessed at April 15, 2015].

[33] NREL. BEopt. Available at: https://beopt.nrel.gov/ [Accessed at April 15, 2015].

[34] TEK07, Byggteknisk forskrift (TEK), Lovdata, Ed. 2007, Norsk Lovtidend

[35] TEK10, Byggteknisk forskrift (TEK), Lovdata, Ed. 2010, Norsk Lovtidend

[36] NS3700, Kriterier for passivhus og lavenergihus. Boligbygninger 2010, Standard

Norge.

[37] Cole, W. J., Powell, K. M., Hale, E. T., and Edgar, T. F. Reduced-order residential home modeling for model predictive control. Energy and Buildings 2014; 74(2014) 69-77.

[38] Lee SH, Fei Z, Augenbroe G, The Use of Normative Energy Calculation Beyond Building Performance Rating Systems, Proceedings of Building Simulation 2011, 12th Conference of International Building Performance Simulation Association, Sydney, 14-16 November.

[39] Poel B, van Cruchten G, and Balaras C. Energy performance assessment of existing dwellings. Energy and Buildings 2007; 39(4): 393-403.

[40] Roulet C, and Anderson B. CEN Standards for Implementing the European Directive on Energy Performance of Buildings. In Passive and Low Energy Architecture. Geneva, Switzerland, September 682006.

[41] Lee SH, Zhao F, and Augenbroe G. The use of normative energy calculation beyond building performance rating. Journal of Building Performance Simulation 2013; 6(4): 282-292.

[42] Guzowski LB, Graziano DJ, Heo Y, Muehleisen RT. Testing a Streamlined Project Evaluation Tool for Risk-Conscious Decision Making: The Chicago Loop Energy Efficiency Retrofit Initiative. 2012 ACEEE Summer Study on Energy Efficiency in Buildings, 2012; 13-139 to 13-151. 
[43] Heo Y, Zhao F, Lee SH, Sun Y, Kim J, Augenbroe G, Graziano D, Guzowski LB, and Muehleisen RT. Scalable Methodology for Energy Efficiency Retrofit Decision Analysis. In SimBuild. Madison, WI. August 1-3, 2012.

[44] Muehleisen RT, Craig B, Macumber D, Hale E, Turner J. Integration of the CEN/ISO Monthly Building Energy Model into OpenStudio. 2014 ACEEE Summer Study on Energy Efficiency in Buildings, 2014.

[45] ANSI/ASHRAE/IESNA. 2010. ANSI/ASHRAE/IESNA 90.1-2010, Energy Standard for Buildings Except Low-Rise Residential Buildings. American Society of Heating, Refrigerating and AirConditioning Engineers, Atlanta, Georgia, 2012.

[46] Fleming K, Long N, Swindler A, The Building Component Library: An Online Repository to Facilitate Building Energy Model Creation, National Renewable Energy Laboratory, Conference Paper (NREL/CP-5500-54710) 2012; 1-12.

[47] Kissock JK, Haberl JS, Claridge DE, Development of a Toolkit for Calculating Linear, Changepoint Linear and Multiple-Linear Inverse Building Energy Analysis Models, ASHRAE Research Project 1050-RP, Atlanta, GA 2002; 1-180.

[48] Lehar MA, and LR Glicksman. 2003. "A simulation tool for predicting the energy implications of advanced facades." Research In Building Physics. (ed. J. Carmeliet, H. Hens, and G.Vermeir), A.A. Balkema. Ch.3, 513-8. Tokyo.

[49] Urban BJ, and Glicksman LR “The MIT Design Advisor - a Fast, Simple Tool for Energy Efficient Building Design," Proceedings of the 2nd National IBPSA-USA Conference, Cambridge, Mass 2006. [50] Architectural Energy Corp., Title 24, Nonresidential ACM Reference Manual, Version 4.3 
consistent with the CBECC-Com v3 release, Aug. 2014.

[51] California Energy Code, Title 24, Building Energy Efficiency Standards, International Code Council, Washington D.C., 2013.

[52] Energy Impact Illinois. 2013. EnCompass. Retrieved from encompass.energyimpactillinois.org, accessed on December 8, 2014.

[53] Energy \& Environmental Modeling and Solution LLC. Models. Tools. Available at: http://www.energyenviromodeling.com/models.html [Accessed November 23, 2013].

[54] Energy \& Environmental Modeling and Solution LLC. and WizClique Software Inc. Energy Savings Benefits Evaluator for Enterprise Customer User’s Manual, 2013.

[55] 2009 ASHRAE Handbook - Fundamentals (SI Edition). American Society of Heating, Refrigerating and Air-Conditioning Engineers, Inc., 2009.

[56] Lee SH, Hong T, Sawaya G, Chen Y, and Piette MA. DEEP: A Database of Energy Efficiency Performance to Accelerate Energy Retrofitting of Commercial Buildings. American Society of Heating, Refrigerating and Air-Conditioning Engineers 2015 Winter Conference. Chicago, IL. January 24-28, 2015.

[57] Levine M, Feng W, Ke J, Hong T, Zhou N. A Retrofit Tool for Improving Energy Efficiency of Commercial Buildings. In Proceedings of the ACEEE Summer Study Conference, Pacific Grove, CA. August 12-17, 2012.

[58] Pan Y, Xu Z, and Li Y. Evaluating Commercial Building Retrofit Energy Saving by Using a Building Retrofit Tool - Case Studies in Shanghai. In ASim 2012. Shanghai China.

[59] Mills E, Mathew P, Bourassa N, Brook M and Piette MA. Action-Oriented Benchmarking: 
Concepts and Tools. Energy Engineering 2008; 105(4): 21- 40.

[60] Mathew P, Mills E, Bourassa N, Brook M. Action-Oriented Benchmarking: Using the CEUS Database to Benchmark Commercial Buildings in California. Energy Engineering 2008; 105 (5), 6- 18. [61] Heo Y, Choudhary R, Augenbroe GA, Calibration of building energy models for retrofit analysis under uncertainty. Energy and Buildings 47 (2012) 550-560.

[62] ASHRAE. Guideline 14-2002: Measurement of Energy and Demand Savings. American Society of Heating, Refrigerating and Air-Conditioning Engineers, Atlanta 2002.

[63] Remer DA, and Nieto AP. A compendium and comparison of 25 project evaluation techniques. Part 1. Net present value and rate of return methods. International Journal of Production Economics 1995; 42: 79-96.

[64] Mahdavi A, Pont U, Shayeganfar F, and Ghiassi N. SEMERGY: Semantic web technology support for comprehensive building design assessment, eWork and eBusiness in Architecture, Engineering and Construction, Taylor \& Francis Group, London, 2012.

[65] Hitchcock R J, Carroll WL, and Birdsall BE. Retrofit Energy Savings Estimation Model Reference Manual. LBNL-51874. 1991.

[66] Carroll WL. High Performance Commercial Building Systems: RESEM-CA Final Project Report. LBNL-57775. 2004.

[67] Alajmi A. Energy audit of an educational building in a hot summer climate. Energy and Buildings 2012; 47: 122-130. 
Figure 1: A schematic detailing the general features of a retrofit toolkit and the toolkits reviewed separated by the type of the building energy simulation engine.

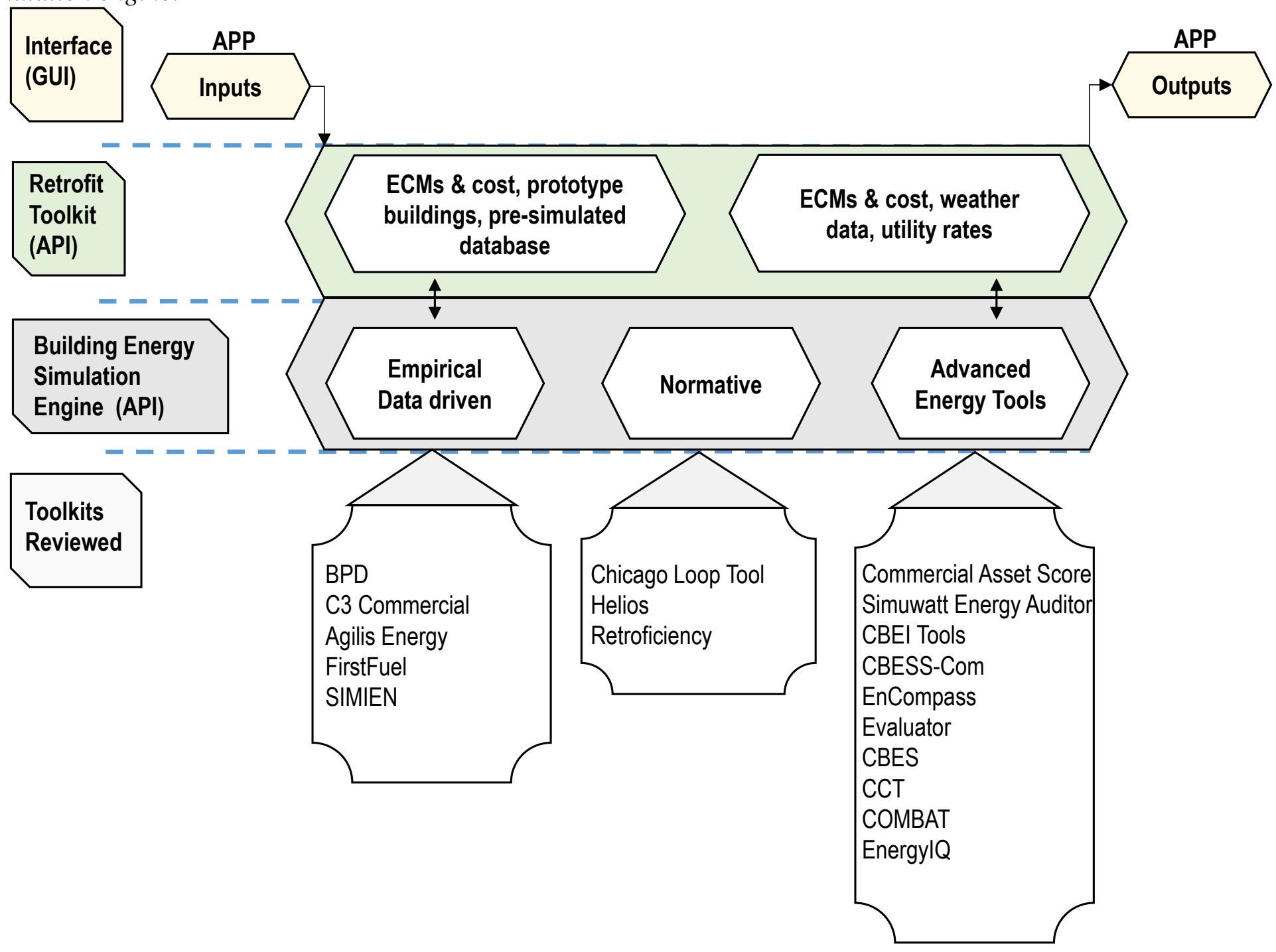


Table 1: A list of the reviewed toolkits.

\begin{tabular}{|c|c|}
\hline \multicolumn{2}{|r|}{ Toolkit Name } \\
\hline 1 & Buildings Performance Database (BPD) \\
\hline 2 & C3 Commercial \\
\hline 3 & Agilis Energy \\
\hline 4 & FirstFuel \\
\hline 5 & SIMIEN \\
\hline 6 & Chicago Loop Energy Retrofit Tool \\
\hline 7 & HELiOS Building Energy Efficiency \\
\hline 8 & Retroficiency \\
\hline 9 & $\begin{array}{c}\text { Commercial Building Energy Asset Scoring } \\
\text { Tool }\end{array}$ \\
\hline 10 & Simuwatt Energy Audit \\
\hline 11 & $\begin{array}{l}\text { Consortium for Building Energy Innovation } \\
\text { (CBEI) Tools }\end{array}$ \\
\hline 12 & $\begin{array}{l}\text { California Building Energy Code Compliance } \\
\text { for Commercial (CBECC-COM) }\end{array}$ \\
\hline 13 & EnCompass \\
\hline 14 & $\begin{array}{l}\text { The Energy Savings Benefits Evaluator for } \\
\text { Enterprise Customers (Evaluator) }\end{array}$ \\
\hline 15 & Commercial Building Energy Saver (CBES) \\
\hline 16 & Customized Calculation Tool (CCT) \\
\hline 17 & $\begin{array}{c}\text { Commercial Building Analysis Tool } \\
\text { (COMBAT) }\end{array}$ \\
\hline 18 & EnergyIQ \\
\hline
\end{tabular}


Table 2: A list of the toolkits using empirical data-driven statistical methods with the general input requirements.

\begin{tabular}{|c|c|c|c|c|c|}
\hline \multicolumn{6}{|c|}{$\begin{array}{l}\text { Empirical data-driven Toolkits } \\
\end{array}$} \\
\hline General Information & $\begin{array}{l}\text { 1. Building } \\
\text { Performance } \\
\text { Database } \\
\text { (BPD) } \\
\end{array}$ & $\begin{array}{c}\text { 2. C3 } \\
\text { Commercial }\end{array}$ & $\begin{array}{l}\text { 3. Agilis } \\
\text { Energy }\end{array}$ & 4. FirstFuel & 5. SIMIEN \\
\hline URL & bpd.lbl.gov & $\begin{array}{l}\text { c3energy.com/pro } \\
\text { duct-commercial }\end{array}$ & $\begin{array}{c}\text { agilisenergy.co } \\
\mathrm{m}\end{array}$ & firstfuel.com & $\begin{array}{c}\text { programbyggern } \\
\text { e.no }\end{array}$ \\
\hline Developer/Sponsor & $\begin{array}{l}\text { LBNL, PNNL/ } \\
\text { DOE }\end{array}$ & C3 Energy & Agilis & FirstFuel & $\begin{array}{c}\text { ProgramBygger } \\
\text { ne ANS }\end{array}$ \\
\hline Target Audience & $\begin{array}{c}\text { Building } \\
\text { Owner, Energy } \\
\text { Manager }\end{array}$ & $\begin{array}{l}\text { Utility Customers } \\
\text { (Building Owner, } \\
\text { Energy Manager) }\end{array}$ & $\begin{array}{c}\text { Building } \\
\text { Owner, Energy } \\
\text { Manager }\end{array}$ & $\begin{array}{c}\text { Building } \\
\text { Owner, Energy } \\
\text { Manager }\end{array}$ & $\begin{array}{l}\text { Building Owner, } \\
\text { Energy Manager }\end{array}$ \\
\hline Type & web-based & web-based & web-based & web-based & web-based \\
\hline Accessibility for the public & Yes & No & No & No & Yes \\
\hline Utility bills & $\begin{array}{c}\mathrm{x} \text { (Yearly } \\
\text { source and site } \\
\text { EUI) }\end{array}$ & $\mathrm{x}$ & $\mathrm{x}$ & $\mathrm{x}$ & \\
\hline $\begin{array}{c}\text { Time series interval energy } \\
\text { data }\end{array}$ & & $\mathrm{x}$ & $\mathrm{x}$ & $\mathrm{x}$ & \\
\hline Utility rates & & & & & $\mathrm{x}$ \\
\hline Calibration & & & & & $\mathrm{x}$ \\
\hline Climate data & $\begin{array}{c}\text { x (Indicate } \\
\text { climate zone) }\end{array}$ & $\begin{array}{l}\mathrm{x} \text { (Impacts of } \\
\text { climate } \\
\text { calculated) }\end{array}$ & $\mathrm{x}$ & & $\begin{array}{l}\text { x (Cold } \\
\text { climates })\end{array}$ \\
\hline Operation hours & & unknown & & & $\mathrm{x}$ \\
\hline
\end{tabular}




\begin{tabular}{|c|c|c|c|c|c|}
\hline Location & U.S. & U.S. & U.S. & U.S. & $\begin{array}{l}\text { Scandinavian } \\
\text { countries }\end{array}$ \\
\hline $\begin{array}{l}\text { I'Simple system } \\
\text { characteristics }\end{array}$ & $\mathrm{x}$ & $\mathrm{x}$ & $\mathrm{x}$ & $\mathrm{x}$ & \\
\hline $\begin{array}{l}{ }^{2} \text { Simple building } \\
\text { characteristics }\end{array}$ & $\mathrm{x}$ & $\mathrm{x}$ & $\mathrm{x}$ & $\mathrm{x}$ & \\
\hline $\begin{array}{c}{ }^{3} \text { Detailed systems } \\
\text { characteristics }\end{array}$ & & & & & $\mathrm{x}$ \\
\hline $\begin{array}{c}{ }^{3} \text { Detailed building } \\
\text { characteristics }\end{array}$ & & & & & $\mathrm{x}$ \\
\hline
\end{tabular}

${ }^{1}$ Simple System Characteristics: This includes lighting, heating/cooling, wall insulation, window type and roof characteristics ${ }^{2}$ Simple Building Characteristics include building type, vintage, floor area, occupant density ${ }^{3}$ Detailed System and Building Characteristics goes beyond that listed in the simple category

LBNL: Lawrence Berkeley National Laboratory, PNNL: Pacific Northwest National Laboratory, ANA: Argonne National Laboratory, DOE: Department of Energy, PG\&E: Pacific Gas \& Electric Company, SDG\&E: San Diego Gas \& Electric, SCE: Southern California Edison, CEC: California Energy Commission 
Table 3: A list of the toolkits using empirical data-driven statistical methods and highlighting primary features, gaps, general ECM categories and general outputs (updated from [6]).

\begin{tabular}{|c|c|c|c|c|c|c|}
\hline Tools & $\begin{array}{l}\text { Target } \\
\text { Buildings }\end{array}$ & $\begin{array}{l}\text { Calculation } \\
\text { Engine }\end{array}$ & Features & Gaps & ECM Categories & Outputs \\
\hline \multirow[t]{2}{*}{$\begin{array}{l}\text { 1. Building } \\
\text { Performance } \\
\text { Database } \\
\text { (BPD) }\end{array}$} & \multirow[t]{2}{*}{$\begin{array}{l}\text { Residential } \\
\text { and } \\
\text { commercial } \\
\text { buildings }\end{array}$} & \multirow[t]{2}{*}{$\begin{array}{l}\text { Real measured } \\
\text { data, retrofit } \\
\text { projects }\end{array}$} & $\begin{array}{l}\text { This publically available, } \\
\text { web-based tool conducts } \\
\text { statistical analysis using } \\
\text { anonymous actual building } \\
\text { energy data }\end{array}$ & \multirow{2}{*}{$\begin{array}{l}\text { Limited samples } \\
\text { of peer building } \\
\text { size and } \\
\text { availability of } \\
\text { estimate of } \\
\text { retrofit savings }\end{array}$} & \multirow[t]{2}{*}{$\begin{array}{l}\text { Air flow control, } \\
\text { cooling, heating, } \\
\text { lighting, window } \\
\text { glazing, }\end{array}$} & \multirow[t]{2}{*}{$\begin{array}{l}\text { Energy } \\
\text { savings, } \\
\text { retrofit } \\
\text { cost }\end{array}$} \\
\hline & & & $\begin{array}{l}\text { Performs retrofit analysis } \\
\text { based on real projects }\end{array}$ & & & \\
\hline \multirow[t]{3}{*}{$\begin{array}{l}\text { 2. C3 } \\
\text { Commercial }\end{array}$} & \multirow{3}{*}{$\begin{array}{l}\text { Small and } \\
\text { medium-size } \\
\text { business } \\
\text { customers }\end{array}$} & \multirow[t]{3}{*}{$\begin{array}{l}\text { Smart meter } \\
\text { data, statistical } \\
\text { model, DEER }\end{array}$} & $\begin{array}{l}\text { Uses national, state, and } \\
\text { regional utility building } \\
\text { stock data for benchmarks }\end{array}$ & $\begin{array}{l}\text { Uses proprietary } \\
\text { algorithm }\end{array}$ & \multirow{3}{*}{$\begin{array}{l}\text { Electric lighting, } \\
\text { building envelope, } \\
\text { equipment, HVAC, } \\
\text { service hot water, } \\
\text { operating schedule }\end{array}$} & \multirow{3}{*}{$\begin{array}{l}\text { Energy } \\
\text { savings, } \\
\text { retrofit } \\
\text { cost }\end{array}$} \\
\hline & & & $\begin{array}{l}\text { Compares energy } \\
\text { benchmark to functionally } \\
\text { equivalent average and } \\
\text { high performing buildings }\end{array}$ & $\begin{array}{l}\text { Algorithm used } \\
\text { and API not open } \\
\text { to the public }\end{array}$ & & \\
\hline & & & $\begin{array}{l}\text { Metered data drives } \\
\text { statistical model based on } \\
\text { the inverse modeling } \\
\text { method }\end{array}$ & & & \\
\hline \multirow[t]{3}{*}{$\begin{array}{l}\text { 3. Agilis } \\
\text { Energy }\end{array}$} & \multirow{3}{*}{$\begin{array}{l}\text { US } \\
\text { commercial } \\
\text { and } \\
\text { industrial } \\
\text { buildings }\end{array}$} & \multirow{3}{*}{$\begin{array}{l}\text { Smart meter } \\
\text { data, statistical } \\
\text { model }\end{array}$} & Analyzes smart meter data & $\begin{array}{l}\text { Uses proprietary } \\
\text { algorithm }\end{array}$ & \multirow{3}{*}{$\begin{array}{l}\text { Electric lighting, } \\
\text { building envelope, } \\
\text { equipment, HVAC, } \\
\text { service hot water, } \\
\text { operating schedule }\end{array}$} & \multirow{3}{*}{$\begin{array}{l}\text { Energy } \\
\text { savings, } \\
\text { retrofit } \\
\text { cost }\end{array}$} \\
\hline & & & $\begin{array}{l}\text { Uses 3D graph pattern } \\
\text { recognition technology }\end{array}$ & Not for public use & & \\
\hline & & & $\begin{array}{l}\text { Analyzes energy savings } \\
\text { using statistical } \\
\text { mathematics }\end{array}$ & & & \\
\hline 4. FirstFuel & $\begin{array}{l}\text { US } \\
\text { commercial }\end{array}$ & $\begin{array}{l}\text { Smart meter } \\
\text { data, statistical }\end{array}$ & $\begin{array}{l}\text { Conducts smart meter data } \\
\text { pattern analysis }\end{array}$ & $\begin{array}{l}\text { Uses proprietary } \\
\text { algorithm }\end{array}$ & $\begin{array}{l}\text { Electric lighting, } \\
\text { building envelope, }\end{array}$ & $\begin{array}{l}\text { Energy } \\
\text { savings, }\end{array}$ \\
\hline
\end{tabular}




\begin{tabular}{|c|c|c|c|c|c|c|}
\hline & & model & $\begin{array}{l}\text { Analyzes energy savings } \\
\text { from statistical model }\end{array}$ & Not for public use & $\begin{array}{l}\text { equipment, HVAC, } \\
\text { service hot water, } \\
\text { operating schedule }\end{array}$ & $\begin{array}{l}\text { retrofit } \\
\text { cost }\end{array}$ \\
\hline \multirow[t]{3}{*}{ 5. SIMIEN } & \multirow{3}{*}{$\begin{array}{l}\text { Residential } \\
\text { and } \\
\text { commercial } \\
\text { buildings }\end{array}$} & \multirow{3}{*}{$\begin{array}{l}\text { Smart meter } \\
\text { data (average } \\
\text { monthly } \\
\text { values), semi- } \\
\text { dynamic model }\end{array}$} & $\begin{array}{l}\text { Conducts smart meter data } \\
\text { pattern analysis }\end{array}$ & $\begin{array}{l}\text { Uses proprietary } \\
\text { algorithm }\end{array}$ & \multirow{3}{*}{$\begin{array}{l}\text { Electric lighting, } \\
\text { building envelope, } \\
\text { equipment, HVAC, } \\
\text { service hot water, } \\
\text { operating schedule }\end{array}$} & \multirow{3}{*}{$\begin{array}{l}\text { Energy } \\
\text { savings, } \\
\text { retrofit } \\
\text { cost, IAQ }\end{array}$} \\
\hline & & & $\begin{array}{l}\text { Analyzes energy savings } \\
\text { from semi-dynamic model, } \\
\text { including benchmarking } \\
\text { compared with low energy } \\
\text { buildings }\end{array}$ & Not for public use & & \\
\hline & & & $\begin{array}{l}\text { Follow-through } \\
\text { measurement and } \\
\text { verification after } \\
\text { implementation }\end{array}$ & Not for public use & & \\
\hline
\end{tabular}


Table 4: A list of the toolkits using normative calculation methods with the general input requirements.

\begin{tabular}{|c|c|c|c|}
\hline \multicolumn{4}{|c|}{ Normative Toolkits } \\
\hline General Information & $\begin{array}{c}\text { 1. Chicago Loop } \\
\text { Energy Retrofit } \\
\text { Tool }\end{array}$ & 2. HELiOS & 3. Retroficiency \\
\hline URL & N/A & heliosbe.com & retroficiency.com \\
\hline Developer/Sponsor & ANL/DOE & $\begin{array}{l}\text { HELiOS Building } \\
\text { Efficiency }\end{array}$ & Retroficiency \\
\hline Target Audience & $\begin{array}{c}\text { Building Owner, } \\
\text { Energy Manager, } \\
\text { Policy Maker }\end{array}$ & $\begin{array}{l}\text { Building Owner, } \\
\text { Energy Manager }\end{array}$ & $\begin{array}{l}\text { Building Owner, } \\
\text { Energy Manager }\end{array}$ \\
\hline Type & stand-alone & web-based & web-based \\
\hline Accessibility for the public & No & No & No \\
\hline Utility bills & $\mathrm{x}$ & $\mathrm{x}$ & $\mathrm{x}$ \\
\hline Time series interval energy data & & tbd & $\mathrm{x}$ \\
\hline Utility rates & $\mathrm{x}$ & $\mathrm{x}$ & $\mathrm{x}$ \\
\hline Calibration & $\mathrm{x}$ & $\mathrm{x}$ & $\mathrm{x}$ \\
\hline Climate data & $\mathrm{x}$ & $\mathrm{x}$ & $\mathrm{x}$ \\
\hline Operation hours & $\mathrm{x}$ & $\mathrm{x}$ & $\mathrm{x}$ \\
\hline Location & Chicago area only & U.S. & U.S. \\
\hline${ }^{1}$ Simple system characteristics & $\mathrm{x}$ & $\mathrm{x}$ & $\mathrm{x}$ \\
\hline${ }^{2}$ Simple building characteristics & $\mathrm{x}$ & $\mathrm{x}$ & $\mathrm{x}$ \\
\hline${ }^{3}$ Detailed systems characteristics & $\mathrm{x}$ & $\mathrm{x}$ & $\mathrm{x}$ \\
\hline${ }^{3}$ Detailed building characteristics & $\mathrm{x}$ & $\mathrm{x}$ & $\mathrm{X}$ \\
\hline
\end{tabular}

${ }^{1}$ Simple System Characteristics: This includes lighting, heating/cooling, wall insulation, window type and roof characteristics 
${ }^{2}$ Simple Building Characteristics include building type, vintage, floor area, occupant density ${ }^{3}$ Detailed System and Building Characteristics goes beyond that listed in the simple category LBNL: Lawrence Berkeley National Laboratory, PNNL: Pacific Northwest National Laboratory, ANA: Argonne National Laboratory, DOE: Department of Energy, PG\&E: Pacific Gas \& Electric Company, SDG\&E: San Diego Gas \& Electric, SCE: Southern California Edison, CEC: California Energy

Commission

Table 5: A list of the toolkits using normative calculation methods and highlighting the primary features, gaps, general ECM categories and general outputs (updated from [6]).

\begin{tabular}{|c|c|c|c|c|c|c|}
\hline Tools & $\begin{array}{c}\text { Target } \\
\text { Buildings }\end{array}$ & $\begin{array}{l}\text { Calculation } \\
\text { Engine }\end{array}$ & Features & Gaps & ECM Categories & Outputs \\
\hline \multirow[t]{4}{*}{$\begin{array}{l}\text { 1. Chicago } \\
\text { Loop Energy } \\
\text { Retrofit Tool }\end{array}$} & \multirow[t]{4}{*}{$\begin{array}{l}\text { Chicago, IL } \\
\text { downtown } \\
\text { commercial } \\
\text { buildings }\end{array}$} & \multirow[t]{4}{*}{$\begin{array}{l}\text { Normative } \\
\text { calculation } \\
\text { method }\end{array}$} & $\begin{array}{l}\text { This stand-alone tool uses } \\
\text { the normative calculation } \\
\text { method based on CEN / } \\
\text { ISO Standards }\end{array}$ & $\begin{array}{l}\text { Only applicable } \\
\text { to large } \\
\text { commercial } \\
\text { buildings in } \\
\text { downtown } \\
\text { Chicago, IL }\end{array}$ & \multirow[t]{4}{*}{$\begin{array}{l}\text { Electric lighting, } \\
\text { building envelope, } \\
\text { equipment, HVAC, } \\
\text { service hot water, } \\
\text { occupied condition }\end{array}$} & \multirow[t]{4}{*}{$\begin{array}{l}\text { Energy } \\
\text { savings, } \\
\text { retrofit cost, } \\
\text { GHG } \\
\text { emissions }\end{array}$} \\
\hline & & & $\begin{array}{l}\text { Tests retrofit scenarios } \\
\text { from ECM pallets }\end{array}$ & $\begin{array}{l}\text { Does not capture } \\
\text { dynamic behavior } \\
\text { and control }\end{array}$ & & \\
\hline & & & $\begin{array}{l}\text { Benchmarks energy } \\
\text { against reference buildings }\end{array}$ & $\begin{array}{l}\text { Not accessible by } \\
\text { public }\end{array}$ & & \\
\hline & & & $\begin{array}{l}\text { Supports uncertainty- } \\
\text { embedded retrofit decision }\end{array}$ & & & \\
\hline 2. HELiOS & $\begin{array}{l}\text { US } \\
\text { commercial } \\
\text { buildings }\end{array}$ & $\begin{array}{l}\text { Normative } \\
\text { calculation } \\
\text { method }\end{array}$ & $\begin{array}{l}\text { This stand-alone tool uses } \\
\text { the normative calculation } \\
\text { monthly and hourly } \\
\text { method based on CEN / }\end{array}$ & Not for public use & $\begin{array}{l}\text { Heating, cooling, } \\
\text { ventilation, lighting, } \\
\text { plug loads, pumps, } \\
\text { domestic hot water }\end{array}$ & $\begin{array}{l}\text { Energy } \\
\text { savings, } \\
\text { retrofit cost, } \\
\text { finacial }\end{array}$ \\
\hline
\end{tabular}




\begin{tabular}{|c|c|c|c|c|c|c|}
\hline & & & ISO Standards & & \multirow[t]{4}{*}{$\begin{array}{l}\text { systems, operation } \\
\text { recommendations }\end{array}$} & \multirow[t]{4}{*}{$\begin{array}{l}\text { analysis, risk } \\
\text { analysis }\end{array}$} \\
\hline & & & $\begin{array}{l}\text { Comprehensive retrofit } \\
\text { measures }\end{array}$ & & & \\
\hline & & & $\begin{array}{l}\text { Bayesian calibration } \\
\text { method of energy model } \\
\text { to measured data }\end{array}$ & & & \\
\hline & & & $\begin{array}{l}\text { Risk and financial analysis } \\
\text { to guarantee energy } \\
\text { savings }\end{array}$ & & & \\
\hline \multirow[t]{2}{*}{$\begin{array}{l}\text { B. } \\
\text { Retroficiency }\end{array}$} & \multirow{2}{*}{$\begin{array}{l}\text { US } \\
\text { commercial } \\
\text { and } \\
\text { industrial } \\
\text { portfolio }\end{array}$} & \multirow{2}{*}{$\begin{array}{l}\text { Smart meter } \\
\text { data, } \\
\text { statistical } \\
\text { model, } \\
\text { normative } \\
\text { model } \\
\end{array}$} & \multirow{2}{*}{$\begin{array}{l}\text { This web based tool } \\
\text { conducts two levels of } \\
\text { analysis based on } \\
\text { measured data driven } \\
\text { analysis and normative } \\
\text { energy calculation method }\end{array}$} & $\begin{array}{l}\text { Uses proprietary } \\
\text { algorithm }\end{array}$ & \multirow{2}{*}{$\begin{array}{l}\text { Heating, cooling, } \\
\text { ventilation, lighting, } \\
\text { plug loads, pumps, } \\
\text { domestic hot water } \\
\text { systems }\end{array}$} & \multirow{2}{*}{$\begin{array}{l}\text { Energy } \\
\text { savings, } \\
\text { retrofit cost }\end{array}$} \\
\hline & & & & Not for public use & & \\
\hline
\end{tabular}


Table 6(a): A list of the toolkits using energy simulation engines with the general input requirements.

\begin{tabular}{|c|c|c|c|c|c|}
\hline \multicolumn{6}{|c|}{ Toolkits using Energy Simulation Engines } \\
\hline $\begin{array}{c}\text { General } \\
\text { Information }\end{array}$ & $\begin{array}{c}\text { 1. Commercial } \\
\text { Building Energy } \\
\text { Asset Scoring Tool }\end{array}$ & $\begin{array}{l}\text { 2. Simuwatt } \\
\text { Energy Audit }\end{array}$ & 3. CBEI Tools & 4. CBECC-Com & 5. EnCompass \\
\hline URL & $\begin{array}{c}\text { buildingenergyscore. } \\
\text { energy.gov }\end{array}$ & simuwatt.com & cbei.psu.edu/ & $\begin{array}{c}\text { bees.archenergy.co } \\
\text { m }\end{array}$ & $\begin{array}{c}\text { encompass.energyimp } \\
\text { actillinois.org/Default } \\
\text {.aspx }\end{array}$ \\
\hline Developer/Sponsor & PNNL, NREL/DOE & $\begin{array}{c}\text { Simuwatt, } \\
\text { Concept3D, NREL } \\
\text { / DOD }\end{array}$ & $\begin{array}{l}\text { Consortium for } \\
\text { Building Energy } \\
\text { innovation }\end{array}$ & $\begin{array}{c}\text { Architectural } \\
\text { Energy } \\
\text { Corporation / CEC }\end{array}$ & $\begin{array}{l}\text { Energy Impact } \\
\text { Illinois }\end{array}$ \\
\hline Target Audience & $\begin{array}{l}\text { Bldg. owner, energy } \\
\text { manager }\end{array}$ & $\begin{array}{l}\text { Federal bldg.. } \\
\text { facility manager }\end{array}$ & $\begin{array}{l}\text { Building owner, } \\
\text { facility manager, } \\
\text { consultants }\end{array}$ & $\begin{array}{l}\text { Architect, engineer } \\
\text { for code } \\
\text { compliance }\end{array}$ & $\begin{array}{l}\text { Bldg owner, energy } \\
\text { manager }\end{array}$ \\
\hline Type & web-based & web-based & web-based & stand-alone API & web-based \\
\hline Simulation Engine & EnergyPlus & EnergyPlus & EnergyPlus & EnergyPlus & $\begin{array}{c}\text { EnergyPlus } \\
\text { (presimulation) }\end{array}$ \\
\hline $\begin{array}{l}\text { Accessibility for the } \\
\text { public }\end{array}$ & Yes & tbd & tbd & Yes & Yes \\
\hline Utility bills & & & $\mathrm{x}$ & & \\
\hline
\end{tabular}




\begin{tabular}{|c|c|c|c|c|c|}
\hline $\begin{array}{c}\text { Time series interval } \\
\text { energy data }\end{array}$ & & & & & \\
\hline \multicolumn{6}{|l|}{ Utility rates } \\
\hline \multicolumn{6}{|l|}{ Calibration } \\
\hline Climate data & $\mathrm{x}$ & $\mathrm{x}$ & $\mathrm{x}$ & $\mathrm{x}$ & \\
\hline Operation hours & & $\mathrm{x}$ & $\mathrm{x}$ & & \\
\hline Location & U.S. & U.S. & U.S. & California, U.S. & Illinois, U.S. \\
\hline $\begin{array}{l}\text { ISimple system } \\
\text { characteristics }\end{array}$ & $\mathrm{x}$ & $\mathrm{x}$ & $\mathrm{x}$ & $\mathrm{x}$ & \\
\hline $\begin{array}{l}{ }^{2} \text { Simple building } \\
\text { characteristics }\end{array}$ & $\mathrm{x}$ & $\mathrm{X}$ & $\mathrm{x}$ & $\mathrm{X}$ & \\
\hline $\begin{array}{l}{ }^{3} \text { Detailed systems } \\
\text { characteristics }\end{array}$ & $\mathrm{x}$ & $\mathrm{X}$ & $\mathrm{X}$ & $\mathrm{X}$ & \\
\hline $\begin{array}{l}\text { Detailed building } \\
\text { characteristics }\end{array}$ & $\mathrm{X}$ & $\mathrm{x}$ & $\mathrm{x}$ & $\mathrm{x}$ & \\
\hline
\end{tabular}

${ }^{1}$ Simple System Characteristics: This includes lighting, heating/cooling, wall insulation, window type and roof characteristics ${ }^{2}$ Simple Building Characteristics include building type, vintage, floor area, occupant density

${ }^{3}$ Detailed System and Building Characteristics goes beyond that listed in the simple category

LBNL: Lawrence Berkeley National Laboratory, PNNL: Pacific Northwest National Laboratory, ANA: Argonne National Laboratory, DOE: Department of Energy, PG\&E: Pacific Gas \& Electric Company, SDG\&E: San Diego Gas \& Electric, SCE: Southern California Edison, CEC: California Energy Commission 
Table 6(b): A list of the toolkits using energy simulation engines with the general input requirements.

\begin{tabular}{|c|c|c|c|c|c|}
\hline \multicolumn{6}{|c|}{ Toolkits using Energy Simulation Engines } \\
\hline $\begin{array}{c}\text { General } \\
\text { Information }\end{array}$ & 6. Evaluator & 7. CBES & 8. CCT & 9. COMBAT & 10. EnergyIQ \\
\hline URL & $\begin{array}{l}\text { www.energyenviromod } \\
\text { eling.com/models.html }\end{array}$ & cbes.lbl.gov & $\begin{array}{l}\text { energyenviromodeli } \\
\text { ng.com/models.html }\end{array}$ & $\begin{array}{l}\text { china.lbl.gov/tools- } \\
\text { guidebooks/combat }\end{array}$ & energyiq.lbl.gov \\
\hline Developer/Sponsor & $\begin{array}{c}\text { Energy \& } \\
\text { Environmental } \\
\text { Modeling and } \\
\text { Solutions LLC }\end{array}$ & CEC & $\begin{array}{c}\text { PG\&E, SDG\&E, } \\
\text { SCE }\end{array}$ & $\begin{array}{l}\text { LBNL / China } \\
\text { Energy Group }\end{array}$ & LBNL/CEC \\
\hline Target Audience & $\begin{array}{l}\text { Bldg. owner, energy } \\
\text { manager }\end{array}$ & $\begin{array}{l}\text { California } \\
\text { Building Owner, } \\
\text { Energy Manager }\end{array}$ & $\begin{array}{l}\text { CA Utility } \\
\text { customers }\end{array}$ & $\begin{array}{l}\text { Bldg. owner, } \\
\text { energy manager }\end{array}$ & $\begin{array}{l}\text { Building Owner, } \\
\text { Energy Manager }\end{array}$ \\
\hline Type & web-based & web-based & $\begin{array}{c}\text { Stand-alone (PG\&E, } \\
\text { SDG\&E)/ web- } \\
\text { based (SCE) }\end{array}$ & stand alone & Web-based \\
\hline Simulation Engine & $\begin{array}{l}\text { EnergyPlus, simplified } \\
\text { algorithm for HVAC } \\
\text { simulation }\end{array}$ & EnergyPlus & DOE 2-2, eQuest & $\begin{array}{c}\text { EnergyPlus } \\
\text { (presimulation) }\end{array}$ & $\begin{array}{c}\text { DOE 2-2, eQuest } \\
\text { (presimulation) }\end{array}$ \\
\hline $\begin{array}{l}\text { Accessibility for the } \\
\text { public }\end{array}$ & No & Yes & Yes & Yes & Yes \\
\hline
\end{tabular}




\begin{tabular}{|c|c|c|c|c|c|}
\hline Utility bills & & $\mathrm{x}$ & $\mathrm{x}$ & $\mathrm{x}$ & \multirow{3}{*}{$\begin{array}{l}\text { Based on the } \\
\text { CEUS survey data } \\
\text { and pre-simulation } \\
\text { data using eQuest } \\
\text { for energy saving } \\
\text { data establishment }\end{array}$} \\
\hline $\begin{array}{c}\text { Time series interval } \\
\text { energy data }\end{array}$ & & $\mathrm{x}$ & & & \\
\hline Utility rates & Energy use tariff & $\mathrm{x}$ & $\mathrm{x}$ & & \\
\hline Calibration & & $\mathrm{x}$ & & $\mathrm{x}$ & \\
\hline Climate data & $\mathrm{x}$ & $\mathrm{x}$ & unknown & $\mathrm{X}$ & $\mathrm{x}$ \\
\hline Operation hours & unknown & $\mathrm{x}$ & unknown & unknown & \\
\hline Location & New York, U.S. & California, U.S. & California, U.S. & China & U.S. \\
\hline $\begin{array}{l}\text { ISimple system } \\
\text { characteristics }\end{array}$ & $\mathrm{x}$ & $\mathrm{x}$ & $\mathrm{x}$ & $\mathrm{x}$ & $\mathrm{x}$ \\
\hline $\begin{array}{l}{ }^{2} \text { Simple building } \\
\text { characteristics }\end{array}$ & $\mathrm{x}$ & $\mathrm{x}$ & $\mathrm{x}$ & $\mathrm{x}$ & $\mathrm{x}$ \\
\hline $\begin{array}{l}{ }^{3} \text { Detailed systems } \\
\text { characteristics }\end{array}$ & & $\mathrm{x}$ & $\mathrm{x}$ & & \\
\hline $\begin{array}{c}{ }^{3} \text { Detailed building } \\
\text { characteristics }\end{array}$ & & $\mathrm{x}$ & $\mathrm{x}$ & & \\
\hline
\end{tabular}

${ }^{1}$ Simple System Characteristics: This includes lighting, heating/cooling, wall insulation, window type and roof characteristics ${ }^{2}$ Simple Building Characteristics include building type, vintage, floor area, occupant density

${ }^{3}$ Detailed System and Building Characteristics goes beyond that listed in the simple category

LBNL: Lawrence Berkeley National Laboratory, PNNL: Pacific Northwest National Laboratory, ANA: Argonne National Laboratory, DOE: Department of Energy, PG\&E: Pacific Gas \& Electric Company, SDG\&E: San Diego Gas \& Electric, SCE: Southern California Edison, CEC: California Energy Commission 
Table 7: A list of the toolkits using energy simulation engines and highlighting primary features, gaps, general ECM categories and general outputs (updated from [6]).

\begin{tabular}{|c|c|c|c|c|c|}
\hline Tools & $\begin{array}{l}\text { Calculation } \\
\text { Engine }\end{array}$ & Features & Gaps & ECM Categories & Outputs \\
\hline \multirow[t]{4}{*}{$\begin{array}{l}\text { 1. Commercial } \\
\text { Building Energy } \\
\text { Asset Scoring Tool }\end{array}$} & \multirow[t]{4}{*}{$\begin{array}{l}\text { OpenStudio, } \\
\text { EnergyPlus, } \\
\text { FEDS }\end{array}$} & $\begin{array}{l}\text { A web based tool which } \\
\text { scores buildings by use type } \\
\text { on predefined scales and } \\
\text { evaluate buildings systems }\end{array}$ & \multirow[t]{4}{*}{$\begin{array}{l}\text { Considers a limited } \\
\text { number of operational } \\
\text { parameters in ECM } \\
\text { options }\end{array}$} & \multirow{4}{*}{$\begin{array}{l}\text { Electric lighting, } \\
\text { building } \\
\text { envelope, } \\
\text { equipment, } \\
\text { HVAC, service } \\
\text { hot water, } \\
\text { operating } \\
\text { schedule }\end{array}$} & \multirow[t]{4}{*}{$\begin{array}{l}\text { Energy } \\
\text { savings, } \\
\text { retrofit } \\
\text { cost, }\end{array}$} \\
\hline & & $\begin{array}{l}\text { Creates building geometry } \\
\text { using online tool }\end{array}$ & & & \\
\hline & & Accessible to the public & & & \\
\hline & & $\begin{array}{l}\text { Identifies ECMs by FEDS } \\
\text { based on life cycle cost } \\
\text { analysis }\end{array}$ & & & \\
\hline \multirow[t]{2}{*}{$\begin{array}{l}\text { 2. Simuwatt Energy } \\
\text { Audit }\end{array}$} & \multirow[t]{2}{*}{$\begin{array}{l}\text { OpenStudio, } \\
\text { EnergyPlus }\end{array}$} & $\begin{array}{l}\text { Web based tool which uses } \\
\text { online building component } \\
\text { library BCL, a repository of } \\
\text { energy data for ECMs }\end{array}$ & \multirow[t]{2}{*}{$\begin{array}{l}\text { Not accessible by } \\
\text { public }\end{array}$} & \multirow{2}{*}{$\begin{array}{l}\text { Electric lighting, } \\
\text { building } \\
\text { envelope, } \\
\text { equipment, } \\
\text { HVAC, service } \\
\text { hot water, } \\
\text { occupancy or } \\
\text { operating } \\
\text { schedule }\end{array}$} & \multirow{2}{*}{$\begin{array}{l}\text { Energy } \\
\text { savings, } \\
\text { retrofit } \\
\text { cost, light } \\
\text { quality } \\
\text { assurance }\end{array}$} \\
\hline & & $\begin{array}{l}\text { Automates modeling from } \\
\text { geometry capture technology } \\
\text { during walk-though }\end{array}$ & & & \\
\hline $\begin{array}{l}\text { 3. Consortium for } \\
\text { Building Energy }\end{array}$ & $\begin{array}{l}\text { Inverse } \\
\text { Modeling, }\end{array}$ & $\begin{array}{l}\text { A web based tool, accessible } \\
\text { to the public }\end{array}$ & & $\begin{array}{l}\text { Electric lighting, } \\
\text { building }\end{array}$ & $\begin{array}{l}\text { Energy } \\
\text { savings, }\end{array}$ \\
\hline
\end{tabular}




\begin{tabular}{|c|c|c|c|c|c|}
\hline $\begin{array}{l}\text { Innovation (CBEI) } \\
\text { Tools }\end{array}$ & $\begin{array}{l}\text { simplified } \\
\text { simulation, } \\
\text { OpenStudio / } \\
\text { EnergyPlus }\end{array}$ & $\begin{array}{l}\text { Assesses energy performance } \\
\text { using four different } \\
\text { platforms: (1) Lite: Energy } \\
\text { benchmark from monthly } \\
\text { utility data, (2) Partial: } \\
\text { Simplified simulation, (3) } \\
\text { Substantial: Energy audit, } \\
\text { and (4) Comprehensive: } \\
\text { Detailed simulation }\end{array}$ & $\begin{array}{l}\text { Uses different methods } \\
\text { in each level, and may } \\
\text { yield inconsistent } \\
\text { energy performance } \\
\text { assessment and retrofit } \\
\text { recommendations }\end{array}$ & $\begin{array}{l}\text { envelope, plug } \\
\text { loads, HVAC, } \\
\text { service hot water, } \\
\text { occupancy }\end{array}$ & $\begin{array}{l}\text { retrofit } \\
\text { cost, water } \\
\text { savings }\end{array}$ \\
\hline \multirow{3}{*}{$\begin{array}{l}\text { 4. California Building } \\
\text { Energy Code } \\
\text { Compliance for } \\
\text { Commercial } \\
\text { (CBECC-Com) }\end{array}$} & \multirow[t]{3}{*}{$\begin{array}{l}\text { OpenStudio, } \\
\text { EnergyPlus }\end{array}$} & $\begin{array}{l}\text { This stand-alone API } \\
\text { demonstrates compliance } \\
\text { with Title } 242013 \text { and is } \\
\text { accessible to the public }\end{array}$ & \multirow[t]{3}{*}{$\begin{array}{l}\text { Developed for } \\
\text { compliance and code } \\
\text { check-rather than } \\
\text { retrofit analyses }\end{array}$} & \multirow{3}{*}{$\begin{array}{l}\text { Electric lighting, } \\
\text { building } \\
\text { envelope, } \\
\text { equipment, } \\
\text { HVAC, service } \\
\text { hot water, } \\
\text { occupancy or } \\
\text { operating } \\
\text { schedule }\end{array}$} & \multirow[t]{3}{*}{$\begin{array}{l}\text { Energy } \\
\text { savings }\end{array}$} \\
\hline & & $\begin{array}{l}\text { Uses SketchUp for geometry } \\
\text { creation }\end{array}$ & & & \\
\hline & & $\begin{array}{l}\text { Applies to } 16 \text { CA climate } \\
\text { zones }\end{array}$ & & & \\
\hline \multirow[t]{4}{*}{ 5. EnCompass } & \multirow[t]{4}{*}{$\begin{array}{l}\text { EnergyPlus } \\
\text { pre-simulated } \\
\text { data }\end{array}$} & $\begin{array}{l}\text { This web based tool uses } \\
275,000 \text { energy models } \\
\text { stored in the database and is } \\
\text { accessible to the public }\end{array}$ & \multirow{4}{*}{$\begin{array}{l}\text { Only applicable to } \\
\text { Chicago -- large } \\
\text { commercial buildings } \\
\text { with gross area greater } \\
\text { than } 800,000 \mathrm{ft}^{2}\end{array}$} & \multirow{4}{*}{$\begin{array}{l}\text { Electric lighting, } \\
\text { building } \\
\text { envelope, } \\
\text { equipment, } \\
\text { HVAC, service } \\
\text { hot water, } \\
\text { occupancy or } \\
\text { operating } \\
\text { schedule }\end{array}$} & \multirow[t]{4}{*}{$\begin{array}{l}\text { Energy } \\
\text { savings, } \\
\text { retrofit cost }\end{array}$} \\
\hline & & $\begin{array}{l}\text { Selects best-fit model from } \\
\text { inputs }\end{array}$ & & & \\
\hline & & $\begin{array}{l}\text { Benchmarks energy from } \\
\text { CBECS } 2003 \text { and ENERGY } \\
\text { STAR Target Finder }\end{array}$ & & & \\
\hline & & $\begin{array}{l}\text { Develops retrofit analysis } \\
\text { with local incentive } \\
\text { information }\end{array}$ & & & \\
\hline \multirow{2}{*}{$\begin{array}{l}\text { 6. The Energy } \\
\text { Savings Benefits } \\
\text { Evaluator for }\end{array}$} & \multirow{2}{*}{$\begin{array}{l}\text { EnergyPlus, } \\
\text { simplified } \\
\text { algorithm for }\end{array}$} & $\begin{array}{l}\text { Creates an EnergyPlus model } \\
\text { from building profile input }\end{array}$ & $\begin{array}{l}\text { Lacks retrofit measure } \\
\text { cost data }\end{array}$ & \multirow{2}{*}{$\begin{array}{l}\text { Electric lighting, } \\
\text { equipment, } \\
\text { HVAC, service }\end{array}$} & \multirow{2}{*}{$\begin{array}{l}\text { Energy } \\
\text { savings, } \\
\text { GHG }\end{array}$} \\
\hline & & Uses EnergyPlus for heating & Not accessible by & & \\
\hline
\end{tabular}




\begin{tabular}{|c|c|c|c|c|c|}
\hline \multirow{4}{*}{$\begin{array}{l}\text { Enterprise } \\
\text { Customers } \\
\text { (Evaluator) }\end{array}$} & \multirow{4}{*}{$\begin{array}{l}\text { HVAC } \\
\text { simulation }\end{array}$} & and cooling load & public & \multirow{4}{*}{$\begin{array}{l}\text { hot water, HVAC } \\
\text { operation } \\
\text { schedule }\end{array}$} & \multirow{4}{*}{$\begin{array}{l}\text { emissions, } \\
\text { retrofit } \\
\text { cost, IAQ, } \\
\text { water } \\
\text { savings }\end{array}$} \\
\hline & & $\begin{array}{l}\text { Uses simplified algorithm to } \\
\text { simulate HVAC }\end{array}$ & & & \\
\hline & & $\begin{array}{l}\text { Addresses five building types } \\
\text { (office, hospital, education, } \\
\text { retail, technical building) }\end{array}$ & & & \\
\hline & & Covers CA 16 climate zone & No longer supported & & \\
\hline \multirow{4}{*}{$\begin{array}{l}\text { 7. Commercial } \\
\text { Building Energy } \\
\text { Savor (CBES) }\end{array}$} & \multirow[t]{4}{*}{ EnergyPlus } & Accessible to the public & \multirow{4}{*}{$\begin{array}{l}\text { Still under } \\
\text { development }\end{array}$} & \multirow{4}{*}{$\begin{array}{l}\text { Electric lighting, } \\
\text { building } \\
\text { envelope, } \\
\text { equipment, } \\
\text { HVAC, service } \\
\text { hot water, } \\
\text { occupancy or } \\
\text { operating } \\
\text { schedule }\end{array}$} & \multirow{4}{*}{\begin{tabular}{|l|} 
Energy \\
savings, \\
retrofit \\
cost, IAQ \\
advice
\end{tabular}} \\
\hline & & $\begin{array}{l}\text { No- or low-cost } \\
\text { improvement analysis }\end{array}$ & & & \\
\hline & & Preliminary retrofit analysis & & & \\
\hline & & Detailed retrofit analysis & & & \\
\hline \multirow[t]{5}{*}{$\begin{array}{l}\text { 8. Customized } \\
\text { Calculation Tool } \\
(\mathrm{CCT})\end{array}$} & \multirow[t]{5}{*}{$\begin{array}{l}\text { Engage (a } \\
\text { modified } \\
\text { version of } \\
\text { eQUEST) }\end{array}$} & $\begin{array}{l}\text { Uses prototype buildings and } \\
\text { ECMs in the CEC Database } \\
\text { for Energy Efficient } \\
\text { Resources (DEER) }\end{array}$ & \multirow[t]{5}{*}{$\begin{array}{l}\text { Limited to measures } \\
\text { for HVAC, lighting, } \\
\text { auxiliary systems } \\
\text { based on DEER }\end{array}$} & \multirow{5}{*}{$\begin{array}{l}\text { Electric lighting, } \\
\text { building } \\
\text { envelope, } \\
\text { equipment, } \\
\text { HVAC, service } \\
\text { hot water, } \\
\text { occupancy or } \\
\text { operating } \\
\text { schedule }\end{array}$} & \multirow[t]{5}{*}{$\begin{array}{l}\text { Energy } \\
\text { savings, } \\
\text { retrofit cost }\end{array}$} \\
\hline & & $\begin{array}{l}\text { Includes } 16 \text { CA climate } \\
\text { zones }\end{array}$ & & & \\
\hline & & $\begin{array}{l}\text { Estimates peak demand and } \\
\text { energy savings using DOE- } \\
2.2\end{array}$ & & & \\
\hline & & $\begin{array}{l}\text { Stand-alone: PG\&E, } \\
\text { SDG\&E;Web based: SCE }\end{array}$ & & & \\
\hline & & Calculates incentives & & & \\
\hline $\begin{array}{l}\text { 9. Commercial } \\
\text { Building Analysis }\end{array}$ & $\begin{array}{l}\text { Pre-simulated } \\
\text { database }\end{array}$ & $\begin{array}{l}\text { Simplified inputs; Stand- } \\
\text { alone }\end{array}$ & $\begin{array}{l}\text { Only applicable for } \\
\text { retail and hotels in }\end{array}$ & $\begin{array}{l}\text { Envelope, } \\
\text { lighting, }\end{array}$ & $\begin{array}{l}\text { Energy } \\
\text { savings, }\end{array}$ \\
\hline
\end{tabular}




\begin{tabular}{|c|c|c|c|c|c|}
\hline \multirow[t]{3}{*}{ Tool (COMBAT) } & \multirow[t]{3}{*}{$\begin{array}{l}\text { using } \\
\text { EnergyPlus }\end{array}$} & $\begin{array}{l}\text { Pre-simulated data uses } \\
\text { EnergyPlus to generate } \\
\text { before vs. after retrofit } \\
\text { comparison }\end{array}$ & China & \multirow[t]{3}{*}{$\begin{array}{l}\text { appliances, } \\
\text { simplified HVAC } \\
\text { systems }\end{array}$} & \multirow[t]{3}{*}{ retrofit cost } \\
\hline & & $\begin{array}{l}\text { Embedded cost data for } \\
\text { ECMs allows custom inputs }\end{array}$ & & & \\
\hline & & $\begin{array}{l}\text { Provides basic economic } \\
\text { analysis }\end{array}$ & & & \\
\hline \multirow[t]{3}{*}{ 10. EnergyIQ } & \multirow{3}{*}{$\begin{array}{l}\text { CEC } \\
\text { Commercial } \\
\text { End-Use } \\
\text { Survey } \\
\text { CEUS) survey } \\
\text { data, } \\
\text { eQUEST pre- } \\
\text { simulation } \\
\text { data }\end{array}$} & $\begin{array}{l}\text { A web based, action-oriented } \\
\text { benchmarking of building } \\
\text { energy and system features } \\
\text { for public use }\end{array}$ & $\begin{array}{l}\text { Lacks building- } \\
\text { specific retrofit } \\
\text { recommendations }\end{array}$ & \multirow{3}{*}{$\begin{array}{l}\text { Electric lighting, } \\
\text { building } \\
\text { envelope, } \\
\text { equipment, } \\
\text { HVAC, service } \\
\text { hot water, } \\
\text { occupancy or } \\
\text { operating } \\
\text { schedule }\end{array}$} & \multirow{3}{*}{$\begin{array}{l}\text { Energy } \\
\text { savings, } \\
\text { GHG } \\
\text { emissions, } \\
\text { retrofit cost }\end{array}$} \\
\hline & & $\begin{array}{l}\text { Uses CEUS data for CA and } \\
\text { CBECS for USA }\end{array}$ & $\begin{array}{l}\text { Uses limited measure } \\
\text { list from CEUS } \\
\text { database }\end{array}$ & & \\
\hline & & $\begin{array}{l}\text { Recommends retrofits and } \\
\text { analyzes energy savings } \\
\text { based on eQUEST pre- } \\
\text { simulation }\end{array}$ & $\begin{array}{l}\text { Lacks retrofit measure } \\
\text { cost data }\end{array}$ & & \\
\hline
\end{tabular}

